\title{
Черток М.Д. Философия марша
}

Аннотация: Мари как отдельное произведение - это законченное музыкальное сочинение определённой формы и в определённом ритме, призванное обеспечивать стройность движения или удовлетворять потребности слушателя. При поиске ответов на вопросы о роли и месте марша в нашей жизни, мы натолкнулись на методический вакуум, что и послужило причиной выбора в качестве объекта исследования «военный марш» во всех его разновидностях и формах проявления. Предметом исследования в данной статье выступает роль мариа, рассматриваемого как музыкальное произведение, в жизни индивида, коллектива, этноса, в воспитании и философском становлении личности и развитии культуры. Методом исследования является поиск и осмысление информации как о военной музыке в общем, так и о военном марше в частности. Сопоставление полученных знаний различных эпох и культур в области военной науки, воспитании воина, строении и развитии армии, отношении к музыке как важной составляющей культуры. Новизной данного исследования является попытка философского осмысления феномена марша. Сравнение его с другими подвижными видами искусства, анализ философских размыпилений в контексте роли и влияния военного марша на культуру народа. Призыв более пристального внимания к этому уникальному явлению, ставщему не только видом музыкального произведения, но и жанром, который, кроме своей «служебной» деятельности, явился основой для дальнейшего развития музыкального искусства и стал главным в жанровом разделении музыки.

Review: As a musical composition, march is a piece of music of a certain form and with a certain regular rhythm that is written for marching to and satisfying esthetic needs of a listener. In his search for answers to the question about the role and place of march in our life, the author faced the absence of methodological concepts on the matter and therefore chose to study the military march in all its kinds and forms. The subject of the research is the particular role of march as a piece of music in the life of an individual and ethnos, in the process of up-bringing, philosophical achievement of one's personhood and development of culture. The research method is the search for and interpretation of information about the military music in general and military march in particular as well as comparison of discovered facts deriving from different epochs and cultures about military science, raising a warrior, formation and development of the army and attitude to music as an important element of culture. The novelty of the present research is in the attempt to provide a philosophical interpretation of the phenomenon of march, to compare this musical genre with other active branches of art and to analyze philosophical reflections on the role and influence of military march on the national culture. The author of the research article suggests that we should pay more attention to this unique phenomenon that has become not only the kind of musical composition but also the genre which, besides its 'official' purpose, has also created the grounds for further development of musical art and division of music into different musical genres.

Ключевъе слова: мари, музыка, философия, война, религия, обряды, музыкальные инструменты, государство, армия, мир.

Keywords: march, music, philosophy, war, religion, rites, musical instruments, state, army, peace.

Иазвалины звёзд 12-я песнь Заратустры ${ }^{1}$

$\mathrm{M}$ арш - один из древнейших видов творчества, рождение которого связано с моментом возникновения культуры и государственности, появления армии и музыкальных инструментов. Марш является одной из важных форм идеологического воспитания и объединения людей для достижения конкретных целей, причём цели эти направлены на самосохранение, он - неотъемлемая составляющая

\footnotetext{
${ }^{1}$ Ницие Ф.В. Песни Заратустры. СПб.: Азбука.
} 1997. C. 9. человеческого существования. Марш существует с незапамятных времён среди многих исторических народов и рас.

Это древнейшее и целенаправлено «военное» происхождение марша сыграло в его судьбе и негативную роль: многие искусствоведы и эстетики роль марша ограничивали «лишь» потребностями общества для объединения людей, обучения граждан, защиты своего народа и своего государства, считая его прерогативой милитаристски настроенных фанатиков и государственных деятелей. И только единицы трезвых умов уделяли вни- 
мание маршу как достойному явлению бытия и музыкальному произведению, имеющему и заслуживающему более почтительного к себе отношения. К сожалению, голоса этих единиц тонут в общем хоре теоретиков, разрабатывающих новые концептуальные подходы и упорно ищущих сверх идеи.

Однако, при поиске ответов на вопросы о роли и месте марша в нашей жизни, мы натолкнулись на методический вакуум, что и послужило причиной выбора в качестве объекта исследования военный марш во всех его разновидностях и формах проявления. Предметом же выступает роль марша в жизни индивида, коллектива, этноса, в воспитании и философском становлении личности и развитии культуры.

Высокое значение марша в достижении целей самосохранения трудно переоценить, марш позволял народам сохранить себя и отвоевать право жить на своей территории. По этой причине во многих культурах музыке, позволяющей или помогающей защитить себя от врагов, отводилась божественная роль.

Марш по-своему является участником социальной жизни, одной из составляющей человеческой цивилизации, политического и морального закона, он настолько прочно и глубоко вошёл в нашу жизнь, что мы воспринимаем его как нечто естественное.

Марш сопровождает все воинские ритуалы, от самых грустных и неприятных до самых желанных и весёлых. Но главная цель военного марша как музыкального произведения всё же была и остаётся философской - проникнуть в сердца и умы слушателей. По словам Г. Кастнера «армия марширует под ритмичные звуки музыки, упорядочивающей движения. Ею занимаются боги - герои, используя её наряду с танцами для распространения цивилизации и расширения мирным путём подвластных им областей» ${ }^{2}$. Главной же целью нашего исследования выступает поиск новых знаний о философской роли марша в становлении культуры общества и обоснование выделения комплекса этих сведений в отдельную область знаний.

В эстетической литературе почти не существует традиции социально-исторического и культурологического рассмотрения феномена марша. Эстетика его ещё требует своего создателя, и полезными в такой работе окажут-

\footnotetext{
${ }^{2}$ Кастнер Ж. Общее руководство по военной музыки. Париж. 1847. С. 11.
}

ся исследования по общей теории музыки, военному искусству, психологии и педагогике. Своей скромной работой я пытаюсь восполнить образовавшийся кризис и побудить маститых и опытных философов и эстетиков обратить всё же своё внимание на почти нетронутый пласт музыки - марш.

\section{І. ОНТОЛОГИЯ}

\section{1. Философия военной музыки}

В прошлом право сочинять и использовать марши предоставлялось только образованным и высокопоставленным лицам, порою царственным особам, демонстрирующим собой символ и гарант общественного порядка и естественного устройства в мире, что, конечно же, и послужило отнесению марша в область божественного промысла.

В различные исторические периоды развития культуры у философов и правителей по-разному складывались отношения к военной музыке. В Античности такие гиганты как Гомер и Еврипид, Лукиан и Сократ, Платон и Вергилий упоминали о необходимости консолидирующего начала и роли музыки для этой консолидации.

У большинства народов марш служил средством проявления военных и гражданских доблестей. Поэзия, музыка и танец принимали совместное участие в военной жизни, помогая одно другому, для поднятия боевого духа воинов и заполнения их досуга. Известно, что поэзия, музыка и танец имеют общее происхождение, идущее из глубокой древности, а самое слово «музыка» (с греческого - искусство муз) было родовым понятием, сочетающим в себе все эти искусства. Не хотели ли древние выразить этим, что музыка заключает в себе сущность всех искусств?

У древних египтян музыка признавалась частью сокровенных знаний, принесённых богом Тотом, без неё не обходились ни празднования, ни религиозные и торжественные церемонии ${ }^{3}$ ни тем более, боевые действия. Различные музыкальные инструменты изо-

\footnotetext{
3 Такое же значение придавалось музыке в известном, состоявшемся в 284 году до нашей эры в г. Александрии торжестве вступления на престол Птолемея Филадельфа. По сохранённому нам Калисеном Родосским описанию, по великолепию триумфальное шествие заключало в себе среди прочих чудес хор из 600 человек, между которыми выступали 300 кифаристов, имевших инструменты с золотыми рогами и украшениями.
} 
бражались на стенах храмов и гробниц, в знаменитой «Книге мёртвых», а также найдены в гробницах Имаи, Рамсеса IV (2365 г. до н.э.), и, конечно, Тутанхамона (1352 г. до н.э.). В последней знаменитым англичанином Дж. Картером найдены прекрасно сохранившиеся трубы, это указывает на то, что музыкой занимались самые высокопоставленные лица. Так, по словам Страбона, отец Клеопатры, Авлет (Флейтист) Птолемей уже в 15-летнем возрасте свободно играл на флейте. Он «играл на флейте, аккомпанируя хорам, и настолько гордился этим, что не стеснялся устраивать состязания в царском дворце»4. В армии применялись и трубы, но их звук не принадлежал к числу приятных, а, по словам Плутарха, «напоминал крики осла» 5 .

У древних греков, ещё в большей мере, чем у египтян, музыка служила предметом забот философов, математиков и законодателей. Страбон указывает: «Платон называл музыку философией и утверждал, что мир устроен гармонически, причём всё, относящееся к музыке, рассматривал как дело богов» ${ }^{6}$. Плутарх в своём трактате «О музыке» говорит: «музыка - искусство богов - есть искусство во всех отношениях почтенное» ${ }^{7}$. Боги и герои никогда не гнушались музыки. Орфей - знаменитый лирист, при игре которого дикие и самые свирепые звери ложились у его ног, а «Аполлон был даже научен Афиной игре на флейте» ${ }^{8}$.

Аристид Квинтилиан определяет музыку как «искусство прекрасного и соразмерного в голосах и инструментах» ${ }^{9}$. Афиней, говоря о музыке древних аркадян, указывает, что она включает поэзию, пение и танец ${ }^{10}$.

Платон рекомендовал обучение музыке, как «средству развития духовных способностей, и обучение гимнастике ${ }^{11}$, как средству

\footnotetext{
${ }^{4}$ Страбон. География, кн. I, гл. 25.

5 Плутарх. Сравнительные жизнеописания. М.: Альфа-книга: 2008. Ликург и Нума Помпилий, гл. 22. С. 57.

${ }^{6}$ Страбон. География, кн. Х, гл. 10.

7 Плутарх. О музыке. Петроград: Государственное издательство. 1922. С. 50.

${ }^{8}$ Там же. С. 49.

${ }^{9}$ См.: Аристид Квинтилиан. Трактат «О музыке». в трёх книгах. Он сохранился в 56 рукописях, преимущественно XIV-XV вв. (одна рукопись датирована концом XII в.).

${ }^{10}$ См.: Афиней. Пир мудрецов. В 15 кн. Т. 1. Кн. 2. М.: Наука. 2003. С. 38.

${ }^{11}$ Гимнастика состояла из двух разделов: танец и борьба.
}

развития способностей физических» ${ }^{12}$. Занятия музыкой должны вызывать благородные движения души, делать людей лучше и счастливее, а также в совместном действии с гимнастическими упражнениями вносить стройность в физические движения, развивая силу и гибкость. Платону же, между прочим, и принадлежит утверждение, что «движение вселенной и светил слагается и совершается не без участия музыки, так как всё устроено богом согласно требованиям гармонии» ${ }^{13}$, подразумевая физические и математические законы в точном музыкальном соотношении.

Понятие «музыка», взятое в своём наиболее широком смысле, было у древних синонимом порядка и гармонии, вот почему греческие писатели в некоторых случаях употребляли это слово, чтобы выразить совершенный порядок армии, построенной к бою.

То, что уже в древности движение «в ногу» приветствовалось в армии, доказывает Плутарх в своих «жизнеописаниях». Вот что он пишет о боевом строе в Спарте: «Всякий раз, когда построение боевой линии заканчивалось, царь на глазах у противника приносил в жертву козлёнка и подавал знак всем увенчать себя венками, а флейтистам приказывал играть Касторов напев ${ }^{14}$ и одновременно сам затягивал походный пеан. Это было страшное и грандиозное зрелище, как передают писатели, рассказывающие об этом, - видеть войско, движущееся под звуки флейт мерным шагом, в несокрушимом порядке, в непоколебимом и радостном возбуждении. Их ряды были сомкнуты, ничьё сердце не билось от страха, они шли навстречу опасности под звуки флейт и пеанов, спокойно и весело. Нетрудно было предсказать, что они до конца сохранят уверенность и отвагу, как будто их охраняло какое-то благосклонное божество ${ }^{15}$.

Правомерность и полезность использования музыки в армии и в бою Плутарх доказывает в другом жизнеописании - «Агезилай и Помпей»: «Почему партиаты идут в сражение под звуки флейты? - задан был раз

\footnotetext{
12 Платон. Лахес: диалог философа Платона о мужестве. М.: Унив. тип.. 1890. С. 13.

13 Плутарх. О музыке. Петроград: Государственное издательство. 1922. С. 84.

${ }_{14}$ По Ж. Кастнеру, гимн Кастору или Штурмовой марш (marche d'ataque), по В. Алексееву - песнь Костра.

15 Плутарх. Сравнительные жизнеописания. М.: Альфа-книга: 2008. Ликург и Нума Помпилий, гл. 22. С. 63.
} 
вопрос Агезилаю. - Чтобы легко было различить по их мерным шагам, - ответил он, - кто из них трус, а кто храбрец. Ибо точно так же, как ритм анапеста усиливает воодушевление мужественных людей, он вызывает ужас у малодушных; если марширующий неуверенно следует ритму флейты, трусость малодушного становится очевидной» ${ }^{16}$. Естественно, в самом деле, охваченный страхом человек марширует неуверенно, так как чувство страха мешает ему сообразовать свой шаг с точным ритмом барабана ${ }^{17}$. Спарта, выступающая в сознании современников скорее военным лагерем, чем городом, Ликургом названа «городом философов». И это совершенно оправдано, поскольку известна боевая слава спартанцев, известно их презрение к золоту, смерти, тщеславию, а также известна их краткость, меткость мысли и, конечно же, любовь к музыке.

У иудеев военная музыка (иногда называемое трублением в шофар ${ }^{18}$ и шатсотсеро) была целиком связана с культом. Книга Исхода рассказывает, что божественный закон был провозглашён на вершине горы Синай «среди грома, молний и облаков, при нарастающем гласе труб» ${ }^{19}$. Сам Господь дает повеление Моисею: «сделай себе две серебряные трубы, чеканные сделай их, чтоб они служили тебе для созывания общества и для снятия станов» ${ }^{20}$. Более того, трубить предоставлено было одним только священникам, как замечает Блаженный Феодорит, ибо «труба означала Божие призвание» 21 . «Сыны Аароновы, священники, должны трубить трубами: это будет вам постановлением вечным в роды ваши» ${ }^{22}$. Таким образом, трубление - не только привилегия, но и обязанность священников. Во время войны трубы вверялись военачальникам, и, в случае надобности, даже простым сол-

\footnotetext{
16 Плутарх. Сравнительные жизнеописания. М.: Альфа-книга: 2008. Агезилай и Помпей, гл. 19. С. 703. 17 Ритм анапеста, о котором упоминается здесь, наиболее соответствует походному маршу. Он состоит из двух коротких и одной долгой длительности; движение должно быть быстрым.

18 Шофар и шатсостсеро - разновидности древнееврейских сигнальных труб. У Чечотта - Шофферара, также он упоминает флейты Хамель, а двойные - Негилет (Чечотт В.А. История музыки. Киев. 1890. С. 76).

${ }^{19}$ Исход, 20:16, 19.

20 Числа, 10:2.

${ }^{21}$ Феодорит Киррский. Толкование на послание к евреям. СПб., 1843. С. 46.

22 Числа, 10:8.
}

датам. В книге Чисел также сказано: «Когда вы выйдете сражаться против притеснителя, трубите громко в трубы. Предвечный вспомнит о вас и избавит вас от врагов ваших» ${ }^{23}$, и, как бы в подтверждение всех предписаний, данных еврейскому народу законом Моисея, священный текст употребляет следующие примечательные слова: «Да будет это Вам законом из века в век» ${ }^{24}$. Эта внушаемая воинам уверенность в том, что звук труб привлечёт к ним внимание и покровительство Бога, поддерживала в них мужество и возбуждала боевой дух во время битвы. Иосиф Флавий более конкретно описывает использование трубных сигналов: «При снятии лагеря, по первому сигналу трубы выступали в путь три колена, занимавшие восточную часть лагеря; второй сигнал обращён был к южным коленам; потом снимался ковчег, затем западные колена, и, наконец, по третьему, северные» ${ }^{25}$.

Один из древнейших народов мира признал с самого начала своего возникновения драгоценные свойства музыки, и особенно музыки для войска. Согласно преданиям, один из основателей небесной империи великий Фу-Си создал философскую и символическую музыку «юэ», в которую он вложил свои заветные мысли, направленные к благополучию и счастью своего народа. Ему приписывается, между прочим, изобретение большого количества инструментов, в том числе Цинь, инструмента с семью струнами, среди которых имелась струна У-Ванг. Это название, как объясняет принц Тзай-Ю в своём музыкальном трактате ${ }^{26}$, имеет отношение к войне, так как У-Ванг - основатель династии Чжоу - обозначает по-китайски «князь-воитель» ${ }^{27}$. В дальнейшем великий реформатор и основатель нового стиля жизни

\footnotetext{
23 Числа, 10:9.

24 Числа, 10:8.

${ }^{25}$ ИосиФ Флавий. Иудейские древности. СПб. 1900. В 2 т. Т. 2. Гл. ХІ. С. 314.

${ }^{26}$ Об этом упоминает Амио Жан (1718 - 1793), французский миссионер-иезуит, историк и астроном в работе «О китайской музыке», т. VII мемуаров, касающийся китайцев, стр. 55 (Mémoires concernant l'histoire, les sciences, les arts, les mœurs et les usages des Chinois (par les missionnaires de Pékin), 15 vol., Paris, 1776-1789).

27 Это произведение под заглавием «Лю-лю-чинг-ю», т.е. ясное объяснение всего относящегося к «Лю» (китайский термин «Лю» обозначает понятие изменения звука). Принц Чай-ню поднёс рукопись императору Уан-Ли в третью луну года Пинг-Хен, тридцать третьего года цикла и 84-м царствования императора, что соответствует 1596 г. н.э. (там же).
} 
Конфуций, считавший музыку высшей силой, говорил: «чтобы изменить нравы и преобразовать обычаи, нет ничего лучше музыки» ${ }^{2}$. Музыка у китайцев считается гармонией в человеческом обществе. В основе её организации лежит 5-звуковая система «у-шен» ${ }^{29}$, но встречаются мелодические образования, построенные на 12-ступенчатых ладах, называемые «люй-люй». Духовые музыкальные инструменты юэ, ди, чи, сяо (флейты), шэн, юй (духовые органы), били (гобой), рога и иные широко использовались ими в древности в различных ритуалах, хотя в армии, как указывают Сунь-цзы, У-цзы и Вэй Ляо-цзы (названия военных трактатов) и другие, использовались лишь барабаны, литавры, гонги (литофоны) и колокольчики. Традиционная классификация «ба инь» («восемь звуков, издаваемых веществами») - отнесение инструментов к одной из восьми категорий, в зависимости от материала, из которого они сделаны: металл, камень, шёлковые нити, бамбук, тыква, горшечная глина, кожа и дерево ${ }^{30}$, была связана с системой «ба фэн» - «восемь ветров» ${ }^{31}$, соотносимых с направлениями в пространстве ${ }^{32}$.

Мудрец Сунь-цзы в своём «Трактате о военном искусстве» писал о музыке с полным уважением к ней: «Когда говорят, а друг друга не слышат, поэтому изготовляют гонги и барабаны. Гонги, барабаны, знамёна и значки соединяют воедино глаза и уши своих солдат. Поэтому в ночном бою применяют много огней и барабанов, в дневном бою много знамён и значков, этим вводят в заблуждение глаза и уши противника»33.

В Индии музыка всегда считалась философией и одной из наилучших форм искусства, используемых для медитации и поклонения богам. Музыкальным закономерностям была соподчинена вся система мироздания, что отражено в «Махабхарате» и «Рамаяне».

\footnotetext{
${ }^{28}$ Сисаури В.И. Церемониальная музыка Китая и Японии. СПб. Изд. СПбГУ, 2008. С. 12.

${ }^{29}$ Встречаемая, весьма часто, и в русской музыке.

${ }^{30}$ Сисаури В.И. Указ. соч. С. 42.

${ }^{31}$ Ткаченко Г.А. Космос, музыка и ритуал: Миф и эстетика в «Люйши чуньцю». М.: Наука. 1990. С. 55.

${ }^{32}$ Первое упоминание данной системы в связи с музыкальными инструментами встречается в «Го юй»: «Управление [царством] подобно музыке. Музыка подчиняется гармонии, а гармония подчиняется миру среди звуков, т.е. звуки предназначены для придания музыке гармонии, а ноты - для установления мира среди звуков».

33 Сунъ-цззы. Искусство стратегии. М. Эксмо, СПб.: Мидгард, 2006. С.. 101.
}

Каждый определённый звук соответствует цвету, растению, животному, планете, также существует коррелирование элементов музыкального языка с определёнными эмоциональными состояниями, временем года и частью суток, с фундаментальными эстетическими принципами - это придало индийской музыке неимоверную сложность ${ }^{34}$. Даже в наиболее раннем трактате по музыке «Натьяшастре» II века до нашей эры, авторство которого приписывается легендарному Бхарате ${ }^{35}$, отдельные звуковые единицы и простейшие ладо-мелодические образования не связаны с жёсткой метрикой, что уже относит музыку в сферу вне времени и пространства. В «Артхашастре», раннесредневековом трактате по правилам управления государством, для военачальника были определены строгие правила в отношении военной музыки: «Дабы быть довольным повиновением своих войск, для построения войска в сражение следует установить сигналы, подаваемые музыкальными инструментами, знамёнами и флажками: когда следует оставаться на месте, когда идти и когда нападать на врага» ${ }^{6}$. Сигналы эти подавались духовыми инструментами (сушира вадья), к которым относились: флейты, шенаи, нафери и нагасварамы и др., а также ударными (аванаддха вадья), которые включали: табла, пакхаваджи, мриданги и др. ${ }^{37}$

\footnotetext{
34 Чечотт, например, в своём рукописном исследовании по истории музыки Древнего Востока приводит следующую легенду: «Божественная чета Брама и Сарасвати произвела на свет 6 гениев, называемых Кагас - представителей главнейших страстей и выражающих эти страсти ладов. Кагас в свою очередь сочетаются с 5-ю музыкальными нимфами, Кагинис, представительницами ладов, выражающих второстепенные страсти. От сочетания Кагас и Кагинис произошли на свет бесчисленные чады - производные лады - подобно волнам морским, могущим умножаться до бесконечности. В результате на 36 ладах строились бесчисленные мелодии, принимавшиеся за производные лады, числу которых не было конца» (Чечотт В.А. История музыки. Киев. 1890. С. 27).

35 Бхарата - древнеиндийский музыковед, автор «Натьяшастры» - одного из древнейших трактатов по театральному искусству и теории драмы, датируемого учёными периодом с IV века до н. э. по II век н. э. Бхарата считается отцом индийского театра, а «Натьяшастра»- базовым текстом по индийской музыке и танцам.

${ }^{36}$ Артхашастра Каутильи. / Самозванцев А.М. М.: Восточная литература РАН. 2009. С. 129.

${ }_{37}$ См.: Дева Б. Чайтанья. Индийская музыка. М.: Музыка, 1980. С. 44-45.
} 
В жизни византийцев музыка имела наиважнейшее значение. Одно из произведений XII века «Анахарсис» показывает обучение музыке как часть аристократического обучения и высмеивает персонаж, потерпевший неудачу в музыкальном искусстве. Музыка была так же важна, как охота или письмо. Естественно, что полководцы и византийские василевсы обязаны были уметь грамотно применять военную музыку для управления войском и воспитания солдат. Об этом писал Маврикий в своём «Стратегиконе». Наибольшего же расцвета византийская музыка достигла в XIV веке. Совершенно естественным был обмен традициями во время войн с расположенными к северу народами, особенно, с руссами.

Некоторые народы относились к музыке настороженно. Например, в арабской культуре, об этом указывает древнеарабский писатель Ибн-Хальдун. Он пишет, что основатель Ислама Магомет «отнёсся к изящным искусствам точно так же отрицательно, как к ним относился, за исключением музыки, и его великий предшественник Моисей. Магомет запрещал не только живопись и ваяние, но он не благоволил также и к музыке из опасения, чтобы она не лишила его последователей воинственного духа» ${ }^{8}$. И лишь после завоевания арабов персами в VII веке н.э. арабская музыка получила толчок к развитию. Арабы поясняли нерасположение пророка только к «безнравственной музыке, за исключением которой может процветать всякая другая» ${ }^{39}$. Они подарили миру множество ударных инструментов, которые и в наши дни остались неизменными и употребляемыми во всех без исключения армиях мира - это табиль турки, именуемый иногда турецким барабаном, табиль болота, ${ }^{40}$ барабука и др ${ }^{41}$.

В Средние века музыка считалась частью точных наук. Так, Никколо Макиавелли в своём трактате «О военном искусстве», составленный не без влияния трудов Сунь-цзы и У-цзы, обратил внимание на военную музыку и её главенствующую роль в управлении войском на войне и в мирное время: «Пехота должна следовать за знаменем, а знамя - за музыкантами. Если музыканты хороши, то войском командуют они, потому что солдат соразмеряет свой шаг с музыкальным

\footnotetext{
${ }_{38}$ Чечотm В.А. История музыки. Киев. 1890. С. 80. 39 Там же. С. 81.

40 Там же. С. 100.

${ }^{41}$ См. Энциклопедия «Музыкальные инструменты». М. «Дека-ВС». 2008. С. 59-66.
}

тактом и, таким образом, легко сохраняет своё место в строю. У древних были флейты, рожки и другие духовые инструменты, тон которых был установлен в совершенстве. Как танцор двигается в такт музыке, так и войско не расстроится, если правильно идёт под музыку. Разнообразие музыки означает разнообразие движений; одна музыка сменяет другую, когда надо воспламенить, сдержать или совсем остановить воинов. У каждого музыкального строя было своё назначение: дорийский строй внушал спокойствие и твёрдость, фригийский - приводил людей в неистовство. Рассказывают, что Александр, услышав за столом фригийскую музыку, так взволновался, что схватился за оружие» ${ }^{2}$.

Аналогичный текст мы находим у Суньцзы: «По учебному уставу низкорослые вооружены пиками и рогатинами, высокорослые луками и арбалетами, сильные несут знамёна, храбрые несут барабаны и гонги, слабые служат при конях и на кухне, сообразительные берутся в штабы» 43 .

О боевых сигналах управления подразделениями Макиавелли говорит: «Четвёртое упражнение - научить солдат понимать распоряжения командующего по звуку музыки или движению знамени, так как приказания с живого голоса понятны без всякого объяснения. Особенно важны распоряжения, подаваемые музыкой, и потому я скажу вам несколько слов о боевой музыке древних. У лакедемонян, по рассказу Фукидида, господствовала флейта, так как они считали, что под её звуки войска идут мерно и спокойно, без ненужных порывов. У карфагенян этой же цели служила цитра. Лидийский царь Алиат употреблял на войне цитру и флейту. Александр Великий и римляне ввели у себя рога и трубы, находя, что эти инструменты зажигают сердца и заставляют воинов биться с удвоенной силой. Мы же последуем и в этом примеру обоих народов так же, как уже сочетали греческий образец с римским, выбирая оружие войска. При командующем должны быть трубачи, потому что звук трубы не только воспламеняет мужество солдат, но лучше всякого другого инструмента будет слышен среди самого ужасного шума. При начальниках батальонов и бригад находятся барабанщики и флейтисты; они будут играть не так, как сейчас, $a$ как обычно играют на пирах. Звуком трубы ко-

42 Макиавелли Н. О военном искусстве. СПб.: АМФОРА. 1999, С. 90.

43 Сунь-цззы. Указ. соч. С. 150. 
мандующий укажет, должны ли войска стоять на месте, идти вперёд или отступать, надо ли стрелять артиллерии, или выбегать запасным велитам; разнообразие трубного звука ясно покажет солдатам все необходимые движения, а после труб ту же команду повторят барабаны. Упражнение это очень важно и должно повторяться часто. В кавалерии должны быть трубы, но менее громкие и с иным звуком, чтобы лошади не пугались» ${ }^{44}$.

Похожий текст в У-цзы: «Один удар барабана - подготовить оружие, два удара - произвести нужную перестановку, три удара - требование пищи, четыре удара - вооружаться для боя, пять ударов - строиться в ряды. Слушают окончание сигнала барабана и только после этого поднимают знамёна» 45 .

Несколько иное отношение к музыке мы наблюдаем у философов Нового времени, особенно немецкой классической школы.

Кант отводит музыке роль лишь как «искусству прекрасной игры ощущений (которые возбуждаются извне, но игра которых должна обладать всеобщей сообщаемостью), которая может касаться лишь соотношения различных степеней настроенности (напряжённости) чувства, воспринимающего ощущение, то есть его тона; и в этом широком смысле оно может быть разделено на художественную игру ощущений слуха и зрения, то есть на музыку и искусство колорита» ${ }^{46}$.

Гегель называет музыку составляющей философского мира человека как универсума: «Только музыка выполняет идеальность и освобождение в своей своеобразной стихии как задушевности, которая непосредственно становится выражением»47. Музыкальное искусство в этой связи призвано раскрывать истину в чувственной форме, как «нечто внутреннее и неделимое» 48 , в то же время, «уничтожает положительную и постоянную форму фигуральных искусств (архитектуры и скульптуры), не позволяет обратно требовать независимого и продолжительного бытия перед лицом выражаемой мысли»49. Однако, Гегель, в отличие от греческих философов, не считает одну лишь музыку способной «воспламенять

\footnotetext{
${ }^{44}$ Макиавелли Н. Там же. С. 126-127.

45 Сунъ-цзы. Указ. соч. С. 150.

${ }^{46}$ Кант И. Критика способности суждения. Сочинения в шести томах. Т. 5. М., 1966. С. 512.

47 Гегель Г.В.Ф. Лекции по эстетике. Кн. III. М.: Институт философии АН СССР. 1958. С. 134.

${ }^{48}$ Гегель Г.В.Ф. Курс эстетики, или Наука изящного. Кн. II, Музыка, эпическая поэзия. М. 1869, С. 4. ${ }^{49}$ Там же, С. 4.
}

сердца», прямо указывая на своё рационалистско-прагматическое к ней отношение ${ }^{50}$ : «Мы должны отбросить все нелепые толки о могуществе музыки - одной, о чём рассказывают столько баснословных историй древние писатели. В числе чудес древней цивилизации упоминается, будто бы звуки Орфеевой лиры усмиряли диких зверей, которые ложились у его ног; но это достаточно для зверей, а не для людей: для последних требуется содержание какой-нибудь высшей науки»51. Ещё более резко и отрицательно он говорит о военной музыке, отодвигая её «за кулисы» жизни: «Теперь уже мы не почитаем музыку, способную по себе располагать к мужеству и презрению смерти. Итак, теперь почти во всех армиях прекрасная музыка, занимающая воображение солдата, возбуждает его, поддерживает во время марша, ободряет во время атаки, но не думаю, чтобы с ней разбивали неприятеля. Звуки труб и треск барабанов не дают ещё мужества. Нынче верят, что победа приобретается энтузиазмом идей, пушками, гением генералов, а не музыкой, которая только поддерживает силы души, наполненной совсем другой пищей и занятой совсем другими интересами» ${ }^{2}$.

Шеллинг, основоположник другой школы философии, романтической, отводит музыке божественную роль, резко противостоя Гегелю и сочувствуя Канту, впервые пытается придать музыке свойства двойственности и объединения различных начал: «Та форма искусства, в которой реальное единство в чи-

\footnotetext{
$5^{\circ}$ В этих своих суждениях Гегель всё же следует учениям эпикурейцев и, в частности, Секста Эмпирика, своим трактатом «Против музыкантов» сказавший: «Одна и та же мелодия способна возбуждать лошадей, но не способна возбуждать людей, да и лошадей, пожалуй, она способна не возбуждать, а ошарашивать. Именно как носильщики тяжестей или гребцы или исполняющие какое-нибудь другое трудное дело пользуются командой для отвлечения внимания от связанного с этим делом страдания, точно также и те, кто пользуется на войне флейтами или трубами, придумали это не потому, что мелодия способна производить какое-то возбуждающее действие на настроение и быть причиной мужественной воли, но потому что они ревностно старались отвлечь самих себя от беспокойства и смятения, почему и некоторые варвары трубят в круглые раковины и сражаются, ударяя в барабаны. Однако ничто из этого нисколько не обращает к храбрости». Гл. 20, 24. Цит. по кн. Лосев А.Ф. Античная музыкальная эстетика. M. 1960. C. 214.

${ }^{51}$ Гегель Г.В.Ф. Указ. соч. С. 28.

${ }^{2}$ Там же. С. 29.
} 
стом виде, как таковое, становится потенцией, символом, есть музыка»53. Таким образом, музыка, по Шеллингу, имеет и мифологическую природу, ибо «мифология есть необходимое условие и первичный материал для всякого искусства» ${ }^{54}$. Это объясняется тем, что основным источником знаний по музыке для Шеллинга были работы Руссо, в частности, его «Музыкальный словарь». Шеллинг проявлял интерес к музыке сквозь призму общеисторических и теоретических концепций.

Шопенгауэр, также критикуя Гегеля, указывает на «высокомерие разума» - экспансию гегелевского последовательного рационализма, инспирирующую утрированный схематизм гегелевской философии, но говорит о музыке как об отпечатке воли: «Музыка именно такая непосредственная объективация и снимок всей воли, каким оказывается сам мир. Музыка ни в каком виде не снимок идей, а снимок самой воли. Именно поэтому действие музыки настолько же могущественней и проницательнее, чем других искусств, ибо те говорят только о тени, а она о существе»55. Шопенгауэр, сближаясь с мнением древних, «утверждает, что весь мир можно бы назвать воплощённою музыкой, также как и воплощённою волей. Это отождествление музыки с волей едва ли согласно с пессимистической метафизикой и напоминает скорее древнее мистическое пифагорейское учение о гармонии сфер ${ }^{56}$. Но мысли Шопенгауэра вдохновили многих композиторов, и среди них величайший Рихард Вагнер, гениальная музыка которого считается венцом композиторского творения.

Ницше, продолжая мысли Шопенгауэра и проповедуя идеи «сверхчеловека» как антропологизированного образа духа Гегеля, отводит музыке природную роль, навеваемую сверху мысль о необходимости придания порядка всему сущему. В этом контексте Ницше приблизился к древним грекам как никто другой: «В мелодии настолько неприкрыто проявляется пристрастие к узаконенному порядку, так что всё только ещё нарождающееся, бесформенное, произвольное наталкивается на её отчаянное сопротивление, и потому она

53 Шеллинг Ф.В.Й. Философия искусства. М.: Мысль. 1966. С. 195.

${ }^{54}$ Там же. С. 105.

55 Шопенгауэр А. Мир как воля и представление.

Перевод А. Фета. С-Петербург. 1881. С. 305.

${ }^{56}$ Цертелев Д, Эстетика Шопенгауэра. СПб. 1890. C. 46 . звучит каким-то отзвуком былых порядков, господствовавших некогда» ${ }^{57}$. Ницше считает музыку единственным средством, способным «добраться до слуха и сердец людей»58. Придерживаясь же взглядов Шопенгауэра, он называет мир «как воплощённой музыкой, так и воплощённой волей» 59 .

Явно выраженных традиций и тенденций у русской философии как таковой не было, а сама она существовала в растворённом виде в истории, в богословии, в литературе, в искусстве, начав постепенно развиваться только после петровских реформ. Среди русских философов позднего времени лишь А. Лосев в начале XX столетия обратил пристальное внимание на музыку, более конкретно выразив своё к ней отношение: «Музыка - безумие, живущее исполински-сильной жизнью, она сущность, стремящаяся родить свой лик. Она - невыявленная сущность мира, его вечное стремление к Логосу, и муки рождающегося Понятия. Разум видит сущность мира сквозь лики схемы, формы и эйдоса. Музыкальное восприятие видит обнажённую, ничем не прикрытую, ничем не выявленную сущность мира, в-себе-сущность, во всей её нетронутой чистоте и несказанности» ${ }^{60}$. Таким образом, Лосев, являясь почитателем позиций древнегреческих мыслителей, что неоднократно повторяет он сам в своём труде «Античная музыкальная эстетика», поддерживает Шопенгауэра и Ницше, что, конечно же, находит отклик и в моём сердце, а к замечательным мыслям Лосева я вернусь в следующей главе.

Роль марша как вида музыкального искусства не меняло его места и значения в каждую историческую эпоху, несмотря на непрерывно меняющееся содержание жизни, считая его серьёзным, нужным и почтенным фактором. Значение его никогда не тускнело в зоне внимания правителей, военачальников и композиторов. Марш не был доведён до такой степени остракизма, как любой другой жанр музыки, ибо, выполняя предписанные ему объединяющие людей функции и служа совершенно конкретным целям, он подвергался строгой регламентации и защите со стороны военного руководства, вероятно поэтому он и сохранил свою высшую роль

\footnotetext{
${ }^{77}$ Ницие Ф. Весёлая наука. СПб.: Азбука. 1997. С. 167.

${ }_{58}^{8}$ Там же. С. 171.

${ }^{59}$ Ницше $\Phi$. Рождение трагедии из духа музыки. СПб.: Азбука-классика. 2007. С. 135.

6 Лосев А.Ф. Музыка как предмет логики. М.: Издание автора. 1927. С. 30.
} 
и первозданную чистоту. Но почему же в таком случае исследователи до сих пор обходили марш своим вниманием, ведь редкий композитор не имеет его в своём репертуаре?

Сегодня, к сожалению, мы не замечаем роста популярности марша, хотя к этому подталкивают многие причины. Среди социокультурных оснований возможности незначительного роста внимания к маршу можно выделить факт смещения фокуса жизни и искусства в область движения. Современная жизнь с её ростом скоростей требует ритма и делает особенно привлекательным динамические формы искусства, такие как танец и марш. Как отмечает Е. Луговая, «в области философии эта тенденция проявилась в выдвижении на первый план теории «деконструкции», а в художественной сфере обращение к живым, подвижным видам искусства» ${ }^{61}$.

\section{2. Марии и война}

Итак, война есть способ бытия человека в мире и способ преодоления социальных антагонизмов, а поскольку марш служит для человека, не может он не выступать и средством достижения каких-то целей в условиях войны. Война - это цепь организованных и распределённых во времени и пространстве актов насилия, в основе которых - применение оружия. «Война есть вооружённая борьба между государствами или народами» ${ }^{62}$. Вооружённая борьба связывает в единое целое другие формы деятельности человека во время войны: политические, экономические, социальные, организационно-управленческие, дипломатические, агитационно-пропагандистские и другие.

$\Phi$. Достоевский полагал войну не только опасным социальным явлением, но и свидетельством нравственного падения человека, не считая её неизбежной, а ведущие к войне противоречия неразрешимыми ${ }^{63}$ В. Соловьёв, проводя поиски ответа на вопрос, в чём смысл мира, исходил из существования двух видов бытия: «бессмысленное, разрозненное бытие, то есть, Хаос, в котором положение всех существ призрачное и преходящее; другое бытие - осмысленное, объединённое добром, Логосом, в котором реализуется скрытый

\footnotetext{
${ }^{61}$ Луговая Е.К. Философия танца. СПб. 2008. С. 14. 62 Толковый словарь русского языка / Шведова Н.Ю. М. РАН ИРЯ им. В.В. Виноградова. 2007. С. 105. ${ }^{63}$ См.: Достоевский Ф.М. Дневник писателя. Сентябрь-ноябрь 1877года. Л.: Наука 1984. С. 96-145.
}

смысл мира или «всеединство» ${ }^{64}$. В человеке противоборствуют две системы: мир чистых идей, платоновский «идеальный космос» и мир материального существования.

Н. Бердяев называет войну «великим испытанием человека, его силы и способности к самопожертвованию. Война делает человека зверем и героем, варваром и могущественным, будит инстинкты самые низкие и самые высокие» ${ }^{65}$, более конкретно определяя пользу и вред войны. Он также указывает на двойственный её характер.

К сожалению, следует констатировать факт, что насилие и войны составляют существенный элемент бытия человеческого общества. В этой связи вся известная нам до сих пор история человечества во многом является историей войн и насилия, почему история марша и военной музыки рассматривается в этом же контексте и зачастую является предметом презрительного к себе отношения со стороны пацифистов и ценителей «высокого искусства». Не может быть достойна уважения музыка, служащая целям уничтожения живого и средством достижения низменных целей определённого человека или группы людей - политическим средством, хоть она и является «божественным промыслом», по утверждению древних. Но марш как элемент музыкального искусства сохраняет свою роль объекта художественного творчества, а преследуемая при этом определённая цель не является причиной неуважительного к себе отношения. В иных жизненных ситуациях, например, при погребении, марш выполняет другие функции - это тоже не есть причина его забвения.

Весьма интересны взгляды и идеи Клаузевица, который, без сомнения также был знаком с трудами Сунь-цзы и У-цзы, из его упомянутой книги «О войне». Воспитанный под влиянием немецкой школы философии, и особенно Гегеля, он развил теорию о войне и о влиянии на неё политики, предложив вместо громоздких и водянистых определений войны весьма простое и ёмкое - война есть не что иное, как расширенное единоборство: «Если мы захотим охватить мыслью как одно целое всё бесчисленное множество единоборств, из которых состоит война, то

${ }^{64}$ Соловъёв В.С. Философские начала цельного знания. Сочинения в 2-х т. М.: Мысль. 1988, Т. 1, C. 25 .

${ }_{55}$ Бердяев Н.А. Футуризм на войне. М.: Канон+. 2004, C. 40. 
лучше всего вообразить себе схватку двух борцов. Каждый из них стремится при помощи физического насилия принудить другого выполнить его волю; его ближайшая цель сокрушить противника и тем самым сделать его не способным ко всякому дальнейшему сопротивлению» ${ }^{6}$.

Война - это продолжение политики. Когда возникает действие, направленное к реализации какой-то цели, естественно, появляются и преграды. Таким образом, в самом определении политического (в его второй практической половине) уже заложена вероятность противостояния, столкновения с трудностями. Любое политическое действие всегда наталкивается на определённое сопротивление - будь-то помехи или целенаправленное противодействие.

Дуальные символы войны имеют место быть, как бытие всего сущего, в единстве противоположностей. Это наглядно показано в упомянутом выше индийском трактате об основах государственного управления Артхашастре. Высшими кастами традиционного общества являются жрецы (брахманы) и воины (кшатрии). Брахманы в их отношении к «политическому» ответственны за масштабные обобщения, кшатрии - за реализацию планов жрецов. Тот факт, что вторая каста формируется из воинов, очень показателен. Война выступает даже не просто как «продолжение политики», но как «половина политики», вступающая в силу всякий раз, когда требуется реализовать на практике проект, сформованный на основании политической воли. В том же случае, когда мы имеем дело с обществами, возникшими в результате так называемой "революции кшатриев», значение фактора войны ещё более возрастает: «Власть кшатриев, создаваемая брахманством, получающая советы советников, всегда побеждает [и] непобедима, вооружённая в соответствии с руководством ${ }^{67}$.

Представления о войне, вражде, противостоянии и полярности заложены в самых древних мифах, легендах и символах человечества; в них же заложены и методы противодействия острым последствиям этой дуальности. Музыка призвана как возбуждать пыл воинов, так и приводить к умиротворению враждующих. Два противоборствующих начала изображены в древнекитайском символе

\footnotetext{
${ }^{66}$ Клаузевиц К.. О войне. М.: Эксмо, СПб.: Мидгард. 2007. С 19.

${ }^{67}$ Артхашастра. С. 22-23.
}

инь-ян (инь - женское начало, ян - мужское). Этот символ, согласно китайской философии, предопределяет всю структуру мироздания, которая основана на борьбе двух противоположных начал - сухого и влажного, мужского и женского, светлого огня и темной воды и т.д. Безоговорочное принятие двойственности мира высказывает и Сунь-цзы: «Война - это великое дело для государства, это почва жизни и смерти, это путь существования и гибели» ${ }^{68}$. Истолкование этой двойственности существенно различается в зависимости от касты. Если жрец (брахман) видит в подобных символах гармонию и трактует их как образ высшего равновесия, то воины (кшатрии) воспринимают их же как выражение противостояния, вражды, конфликта, заложенных в основе вещей, то есть, дисгармонию. В этой связи, признавая музыку как символ порядка и цивилизации, в Китае долгое время существовал обычай обмазывать кровью приносимых в жертву пленников свои боевые барабаны, помогающие своим небесным звуком воодушевить воинов к победе.

В индуизме существует два направления в толковании природы первоначал: «адвайтоведантизм» и «двайто-ведантизм». Воинское, кшатрийское сознание - по аналогии сознание политических активистов, людей, которые связаны с реализацией проекта и поэтому постоянно имеют дело с преградами, возникающими на пути этой реализации, - тяготеет к дуальному пониманию мира (к двайто-ведантизму). Чем более воинственно государство, чем более воинственна философия политики, чем более отчётливо проявлены черты «революции кшатриев» в том или ином обществе, тем больше внимание уделяется философии войны и дуализму.

В кадуцее, древнегреческом символе Гермеса изображены две змеи, которые сплетаются вокруг жезла. Жезл или общее направление, вокруг которого идёт битва двух змей, символизируют жреческий принцип, осевую гармонию Вселенной, брахмановское начало, а борющиеся змеи - структуру воинского сознания, кшатрийское. Соответственно, «высокую» музыку индуизм воспринимает как символ жезла, лишённую всяческой двойственности, марш же признаётся как символ кшатриев - дуальность.

В «Артхашастре» отражён ещё более глубокий подход к жезлу. Он не просто символ царя, а гарант «благополучия философии, трои-

\footnotetext{
${ }^{68}$ Сунъ-цззы. Указ. соч.. С. 67.
} 
цы вед и учения о хозяйстве». Поэтому «царю, желающему успеха в делах, надо быть всегда с поднятым жезлом» ${ }^{69}$.

Баланс в понимании дуальных символов очень тонок и зависит от толкования. Они могут быть основой дуалистической мифологии, вообще исключающей единство (как это было в зороастрийской религии), а могут вписываться в контекст учения, признающего единство мироздания и высшую инстанцию, где все противоречия снимаются. Для обществ с дуалистической философией война приобретает особо важное значение, воспринимается как некая политическая ось бытия. Древнегреческий философ Гераклит сформулировал философию войны краткой фразой: «Вражда есть отец вещей».

Тем не менее, мечта о мире сопровождала человека на всех ступенях цивилизации, начиная с самых первых шагов его. Идеал жизни без войн, когда в международных отношениях соблюдались бы общепризнанные нормы справедливости, восходит к глубокой древности. Так, в плане идеального государства, предложенного Платоном, нет внутренних военных столкновений, но воздаются почести тому, кто отличился во «втором величайшем виде войны» - в войне с внешними врагами. Аналогична точка зрения на эту тему и Аристотеля: древние греки видели в иностранцах врагов и считали их и все им принадлежавшее хорошей добычей, если её только можно было захватить. Поэтому рабство он считал общественно-необходимым институтом, наиболее откровенно изложив свою точку зрения во взглядах на музыкальное воспитание. У Аристотеля имеется специальное рассуждение на тему о том, что «музыкальное воспитание необходимо проводить только среди свободнорождённых, но никак не среди рабов и не среди ремесленников. Оно не должно преследовать целей ремесла, не должно быть профессиональным ${ }^{70}$.

Аналогичное отношение к рабству было и в Римской империи: римляне называли варварским всё, что не было римским, и говорили: «Для варваров цепи или смерть». Призыв древнеримского мыслителя Цицерона «Пусть оружие уступит место тоге», то есть пусть решает не военная сила, а гражданская власть, фактически не применялся в отношении варваров.

\footnotetext{
${ }^{69}$ Артхашастра. С. 17.

70 Лосев А.Ф. Античная музыкальная эстетика. М.: Госмузиздат. 1960. С. 50-51.
}

Китайская философия в трактате У-цзы в вопросе поиска причин войны и классификации войн, ссылаясь на пятиступенное строение в музыке (пентатонику), называет пять причин и пять видов войн: «Причин, по которым начинается война, - пять: борьба из-за честолюбия, борьба из-за выгод, накопление вражды, внутренние беспорядки, голод. Названий войны также пять: война справедливая, война захватническая, война личная, война насилия, война против самих себя» ${ }^{71}$.

Если посмотреть на вопрос о мире без войн с точки зрения христианской Церкви, то и здесь можно видеть некоторую двойственность. С одной стороны, одной из основополагающих заповедей «Не убий!» объявляла тяжёлым грехом лишение человека жизни. Так, киевский князь Владимир Мономах уговаривал князей русских не проливать христианской крови в великий пост. В то же время проповедь всеобего мира не мешала христианской Церкви освящать многочисленные завоевательские войны.

Так например, архиепископ Александрийский, св. Афанасий Великий в одном из своих посланий писал: «...не позволительно убивати, но убивати врагов на поле брани, и законно и похвалы достойно. Тако великих почестей сподобляются доблестные на брани, и воздвигаются им столпы, возвещающие превосходные их деяния... »72. Аврелий Августин идёт ещё дальше, выдвигая идею «справедливой войны, войны за правое дело, против варваров, вторгшихся в пределы Orbis Romanus, христианского царства - в такой войне христианин мог участвовать, не боясь совершить смертный грех» 73 .

Новое слово о мире сказал буржуазный гуманизм, эпоха которого была временем становления капиталистических отношений. Молодая буржуазия в известной степени была заинтересована и в сохранении мира, и в прекращении феодальных распрей, и в развитии внутренней и международной торговли. Расцвета достиг в ту эпоху и военный марш: он начал приобретать форму и вид современного нынче произведения, сохраняя при этом черты двойственности.

\footnotetext{
${ }^{71}$ Сунь-цзы. Указ. соч. С, 140.

72 Послания св. Афанасия Великого, архиепископа Александрийского, к Аммуну монаху // Книга Правил святых апостол, святых Соборов Вселенских и поместных и святых отец. М. 2004. С. 289.

73 Пенской В.В., Пенская Т.М. Очерки истории военного дела Византии. Белгород.: ООО ИПЦ «ПОЛИТЕРРА». 2011. С. 11.
} 
Уважаемый мною и часто цитируемый музыкальный теоретик, философ и мыслитель Жан Жак Руссо в трактате «Суждение о вечном мире» пишет, что «войны, завоевания и усиление деспотизма взаимно связаны и содействуют друг другу, что в обществе, разделённом на богатых и бедных, на господствующих и угнетённых, частные интересы, то есть интересы властвующих, противоречат общим интересам - интересам народа»74. Он связывал идею всеобщего мира с вооружённым свержением власти правителей, ибо они не заинтересованы в сохранении мира.

Интересны взгляды представителей немецкой классической школы философии. Кант в своём трактате «К вечному миру» впервые высказал догадку об объективной закономерности, ведущей к установлению вечного мира, о неизбежности создания на мирных началах союза народов. Здесь происходит то же, что и с отдельными людьми, объединяющимися в государство, дабы воспрепятствовать взаимному истреблению. Государства вынуждены будут «вступить в союз народов, где каждое, даже самое маленькое государство могло бы ожидать своей безопасности и прав не от своих собственных сил, а исключительно от такого великого союза народов»75.

Как всегда, резким диссонансом здесь звучит теория Гегеля. Абсолютизируя примат всеобщего над единичным, рода над индивидом, он считал, что война приводит в исполнение исторический приговор целым народам, которые не связаны с Абсолютным духом. По Гегелю, война - двигатель исторического прогресса, «война сохраняет здоровую нравственность народов в их индифференции по отношению к определённостям, к их привычности и укоренению, подобно тому, как движение ветра предохраняет озёра от гниения, которое грозит им при длительном затишье, так же как народам - длительный или тем более вечный мир ${ }^{76}$.

Ницше, которого многие считали основоположником нацизма и вдохновителем фашизма, вообще считал христианство «деградацией, декадансом и источником всех войн и страданий, выпавших на долю человечества сразу после появления христианства». «Мир

\footnotetext{
${ }^{74}$ Руссо Ж.Ж. Суждение о вечном мире // Трактаты о вечном мире. М.: Соцэкгиз. 1963.

75 Кант И. Трактат «К вечному миру». Сочинения в 6 томах. Т. 6. (1795) М.: Мысль. 1963.

${ }^{76}$ Гулыга А.В. Немецкая классическая философия. M.: 1986. C. 147.
}

христианства, - писал Ницше, - коренится в извращении естественного мира, он выражает глубочайшую неудовлетворённость реальным»77. Однако, ницшевский певец сверхчеловека Заратустра учил не о насилии, но о самоопределении. Путь к сверхчеловеку - это не путь самоутверждения за счёт слабых, но путь борьбы с единственным и достойным соперником - с самим собой.

Марш, помогая любому народу отстоять себя, помогает и каждому человеку сделаться мужественным и сильным. В борьбе противоположностей всегда находится место маршу: если необходимо - вдохновить сердце воина и объединить разнородное общество; если необходимо - умиротворить враждующих и воспитать терпение.

Пример войны как результат неудачной внешней политики государств является Отечественная война 1812 года. Эта война принесла жертвы и бедствия многим народам, включая также народ Франции, а победителем в той войне оказались отнюдь не французы. Немаловажную роль в достижении победы и прекращении войны сыграла музыка, в чём, собственно, и состоит её основная философская двоякая миссия.

Русские императоры и полководцы всегда отмечали необходимость и важность военной музыки в жизни людей. Это ярко выражено в деятельности российских монархов, особенно Александра I, придававшего огромное ей значение. Именно перед началом войны 1812 года, получив жестокий урок при Аустерлице, император обратил внимание на моральнопсихологическую подготовку французских солдат. В этой связи были значительно увеличены штаты полковых оркестров русской армии, а композиторы и капельмейстеры были озадачены сочинением произведений патриотического характера, в частности, полковых маршей и солдатских песен. Благодаря усилиям в этой области, нам и удалось преодолеть сопротивление столь сильного противника.

Наполеон Бонапарт хоть и не обучался музыке специально, но, прекрасно зная драгоценные свойства военных маршей, в письме инспекторам Парижской школы военных трубачей от 26 июля 1797 года указывал так: «Из всех искусств музыка оказывает самое сильное воздействие на эмоции, а потому законодатель должен её в наибольшей степени поощрять. Пассаж пристойной музыки, написанной рукой мэтра, обязательно растрога-

\footnotetext{
${ }_{77}$ Ницие Ф. Воля к власти. М. Наука. 1994. С. 29.
} 
ет слушателя и гораздо сильнее повлияет на него, нежели хорошее моральное поучение, которое убеждает разум, но не затрагивает нашего привычного поведения ${ }^{78}$.

В данном контексте, возможно, прав П. Залесский, сказав, что «побеждает не армия, побеждает культура страны, организация её армии и воспитание её народа» ${ }^{79}$. Бердяев, сравнивая культуру Германии и России, в этой связи даже предсказал победу России над Германией в Первой Мировой войне: «Известно, что германская армия, обладающая блестящей техникой и изумительной дисциплиной, слишком механистична и автоматична. Русская армия более одухотворена, и её победа будет победой духа над механикой, над механической цивилизацией» ${ }^{80}$.

Теперь, как подметил в отношении двойственной природы музыки Шеллинг, возвращаюсь к двойственной природе марша. С одной стороны, марш как элемент военной музыки, способствует обучению граждан и воинов, зарождению патриотического духа, служит консолидации общества, организации армии и улучшению её управляемости. С другой же стороны, являясь элементом музыки вообще, трактуемой древними как единственно правильный божественный закон, управляемый вселенной, планетами и мироустройством, марш способствует умиротворению людей, выступает «посланцем мира», организатором и вдохновителем мирного строительства и бытия.

\section{3. Мари как атрибут}

Использование марша в качестве траурного атрибута - доказательство дуальности бытия весьма интересно и требует отдельного рассмотрения.

Уже древние считали, что движение происходит в результате чередования противоположностей (верх - низ, сильно - слабо и др.), что движение делает зримым соединение темноты и света в создании нашего тела из земли и неба, сердца и ума, природы и культуры. К чередованиям противоположностей с полным основанием можно отнести чередование

\footnotetext{
${ }_{78}$ Вейдер Б. Блистательный Бонапарт. М.: Международные отношения, 1992. С. 36.

79 Залесский П.И. Грехи старой России и её армии. Цит. по: Григорьев А.Б. Философия войны: Российский военный сборник. М.: Изд. центр «Анкил-воин», 1995. С. 154.

${ }^{80}$ Бердяев Н.А. Указ. соч. С. 42.
}

жизни и смерти. Оно составляет движение в его преувеличенном виде и отмечено многими философами. Марш в медленном темпе в этой роли может выступать связующим звеном между жизнью и смертью без «положительной и постоянной формы», как наиболее близкий «к свободному миру души» ${ }^{81}$. Как неотвратима и неизбежна смерть, также и траурный марш всегда находится в центре внимания композиторов и слушателей. А поскольку движение - это «всеобщий закон, лежащий в основе жизни» ${ }^{82}$, то и марш с медленным темпом движения - признак жизни.

В истории философии смерть вообще не считалась окончанием жизни, а переходом в иную жизнь, на этом постулате была построена вся наука, религия и жизнь. Философы Античности, Средневековья и Ренессанса размышляют в связи с этим лишь о формах существования «другой жизни», а также о более или менее достойном переходе от одного существования к другому. Философия рационализма не замечает «чёрной стены» бессмысленности материального существования, открываемой концепцией существования «другой жизни». Пренебрежение проблемами смысла жизни и смерти порождает сильное противодействие в виде расцвета идеалистических философских теорий, коснувшихся и музыки. Споры эти не утихают и по сей день.

Сознание смертности человека пронизывает весь комплекс его мировоззрения, потому что именно смерть ставит вопрос о смысле жизни. Философская проблема смерти связана с проблемами схоластического характера, восходящими к доисторическим временам и по-разному решаемыми в религиозном и внерелигиозном сознании разных эпох и народов. Очевидно одно: во все времена учение о конечности личного существования корреспондировало с учением о конце вселенной, вбираясь и обобщаясь им с одной стороны и наполняя его живым чувственным началом с другой. Смерть неотвратима и неизбежна вот самое надёжное знание человека о самом себе, при этом она окружена тайной, порождающей многочисленные трактовки в разных религиях, науке и философии. Несмотря на такую «вечность», проблема смерти и по сей день не имеет решения.

Кьеркегор, для которого смерть - вовсе не конец и не эпизод в единственной реальности, каковая является вечная жизнь, повто-

${ }^{81}$ Гегель Г.В.Ф. Указ. соч. С. 14.

82 Ткаченко Г.А. Указ. соч. С, 116. 
ряет слова Августина о том, что «смерть не горька, да и вообще, смерти нет» ${ }^{8}$. По Къеркегору вечная смерть, как и вечная жизнь, недоступна пониманию «естественного человека» и приходит вместе с осознанием греха как смертельной опасности - это главный регулятор, перед которым меркнут прижизненные болезни, нищета, горе, враждебность, огорчения и траур.

Гегель, уходя от прямого ответа на вопрос о смерти, отдаёт всё Богу как вечной жизни, оказывающейся выше и значительнее смерти, а вера в Бога обеспечивает субъекту превосходство над смертью: «по нашим представлениям, смертность есть участь конечного, и в соответствии с этим представлением смерть, если она связывается с Богом, есть лишь перенесение на него определения из сферы несоразмерного ему конечного; следовательно, при таком определении Бог не познаётся истинно. Он как бы ухудшается определением отрицания...» ${ }^{84}$.

Ницше, опровергая все предшествующие теории, вообще называет всю философию проповедью медленной смерти и призывает сверхчеловека к свободному распоряжению собственной жизнью. «Умри вовремя» - говорит он устами Заратустры, и далее: «Умерли все боги, теперь мы хотим, чтобы жил сверхчеловек - такова должна быть в великий полдень наша последняя воля!»85 Всякое, существующее в мире, «должно быть готово к страданиям и гибели, нас принуждают бросить взгляд на ужасы и страдания индивидуального существования, но метафизическое утешение вырывает нас на миг из вихря изменяющихся образов» ${ }^{86}$. Но музыке Ницше умереть не даёт, даже не допускает этого в своих мыслях: «Мы верим в вечную жизнь! - так восклицает трагедия, между тем как музыка есть непосредственная идея этой жизни», отдавая тем самым траурному маршу право «вечной жизни» ${ }^{87}$.

Таким образом, смерть, выступая самым загадочным явлением жизни, переходным моментом, в истории человечества явилась источником мифов и обрядов. Момент ухода из жизни всегда обставлялся торжественно

\footnotetext{
${ }_{83}^{83}$ Августин А. Исповедь. М.: Ренессанс. 1991. С. 314.

84 Гегель Г.Ф. Философия религии. М.: Мысль. 1977. T. 2. C. 25.

${ }_{55}^{5}$ Нице Ф. Так говорил Заратустра. М.: Интербук. 1990. C. 70.

${ }^{86}$ Нuцие Ф. Рождение трагедии из духа музыки. СПб.: Азбука-классики. 2007. С. 138.

87 Там же. С. 137.
}

и величественно. Марш в траурных и погребальных церемониях стал постоянным и неотъемлемым атрибутом, выполняя роль нематериального моста между двумя мирами, миром живых и миром мёртвых, но восприятие чувств и эмоций траурной церемонии и звучания траурного марша доступно, естественно, лишь живым. Этот мост между двумя мирами, марш в полной мере выступает здесь как элемент, объединяющий в себе две противоположности - жизнь и смерть. Траурный марш используется всеми композиторами во все времена и эпохи, он - неотьемлемая часть нашей жизни и смерти. Именно поэтому траурный марш никогда не исчезнет, никогда не потускнеет в своём бытии, никогда не перестанет быть актуальным в композиторском и оркестровом репертуаре.

Следует сказать, что помимо траурных церемоний, марш как атрибут используется в других явлениях: в праздниках, в политике, в войне, в мире - поистине, универсальная применяемость марша как атрибута.

\section{II. ФЕНОМЕНОЛОГИЯ}

\section{1. Бъттие: логос и эйдос.}

Теперь же, оставив позади рассуждения о роли марша в войне и мире, в смерти и жизни, хочу обратить внимание на марш как на элемент бытия, для чего вновь обращаюсь к Лосеву и его феноменологическому методу анализа, определённого им как гилетической, или эйдетически-гилетической логикой; не забывая при этом всю мудрость предшествующих философов. Диалектический момент у Лосева проявляется в том, что он наряду с соловьёвским понятием Логоса (всеединства материи) и эйдоса («сущности предмета, явления» ${ }^{8}$ ), вводит понятие гилетического бытия (от гиле - эйдетическая материя) и меонального бытия (от меон - не-сущее), как иного по отношению к эйдосу. Предлагаемый мною анализ марша хоть и является дискуссионным, но, ввиду практически полного отсутствия работ в данной области, выступает единственным. В нём я иногда прибегаю к онтологическому и феноменологическому сравнению с близкими и аналогичными явлениями (жанрами) музыки - песне и танцу.

Марш - более широкое понятие, чем изобретаемые и вычленяемые его отдельные виды или типы. Расширенное понятие

${ }^{88}$ Лосев А.Ф. Указ. соч. С. 33. 
включает исполнение марша в концертной практике и «марш в жизни» - его роль при ведении боевых действий. Феноменологический анализ марша направлен на рассмотрение не видов и типов марша, встречающихся в некоторых исследованиях, а на «чистое бытие» марша, его идеальную предметность, его сущность, смысл, идею. Идеальная предметность марша не обладает физическими параметрами, не локализована внутри времени и пространства, не тождественна также психическому переживанию, сопровождающему сочинение марша, его исполнение, восприятие и использование.

Лосев логическими средствами выявляет чистое бытие музыки, находя ей место в системе Разума. Опираясь на общую первичную диалектическую схему для любого мыслимого предмета, он выделяет три слоя: логический отвлечённый смысл, метод построения сущности; собственно эйдетический, или «идеальную воплощённость материи в идеальной оптической картине»; меонально-гилетический момент иного, «длительность сущности как таковая, сплошное непрерывное движение от одной части сущности к другой» ${ }^{89}$. Эта стихия сущности, эта текучесть и сплошная непрерывность, становление смысла в недрах самого же смысла есть главная особенность музыки. В «эстетике мы оперируем не только с логически конструируемой предметностью, - отмечает Лосев, - но ещё с тем или иным пониманием этой предметности или с той или иной выразительностью этого предмета»90.

Таким образом, «музыка уничтожает этот мир абстракций и закона основания и конструирует другой мир. Музыка гонит науку и смеётся над ней. Мир - не научен. Мир - музыка, а наука - его накипь и случайное проявление» ${ }^{91}$. В нашей концепции подхода песня, танец и марш есть становление цельной сущности (эйдоса), всех трёх его моментов.

Шелер вводит образ «порыва» как образ жизни, творящего саму реальность и определяющий в ней случайные образы. Сам дух не может обладать изначальной мощью и силой, свои законы он осуществляет, используя энергию порыва. В процессе «взаимного проникновения изначально бессильного духа и изначально демонического, слепого ко всем

\footnotetext{
89 Там же. С.36.

90 Там же. С. 37.

${ }^{91}$ Там же. С. 47.
}

духовным идеям и ценностям порыва»92, в постоянном процессе «оживотворения духа» и находится Универсум. Логос даёт закон творению, но сам не является творческим началом, он способен осуществляться только в ином и посредством иного. Образом жизненного порыва мы можем назвать и марш как художественное произведение.

Шеллинг вводит понятие «символ» как некий оформленный образ, возникающий при восприятии искусства: «Музыка как форма, в которой реальное единство становится символом самого себя, необходимым образом в свою очередь заключает в себе все единства. Ибо реальное единство принимает само себя как потенцию только для того, чтобы снова представить себя как форму абсолютным посредством себя самого. Но каждое единство заключает в своей абсолютности в свою очередь все остальные, следовательно, также и музыку и т. д. ${ }^{93}$.

Взаимоотношение бытия размеренного движения и чистого бытия музыки сложны, но тождественны, также и с логическим бытием разума; сопоставимы они также и по объёму: логическое бытие есть бытие сущего, музыкальное - не-сущего. Марш - синтез первых двух, становление сущего с не-сущим. Эти два типа бытия сходны своей бесформенностью и хаотичностью, сплошной процессуальностью и динамизмом. Музыкальное бытие обладает внепространственностью: «чистое музыкальное бытие есть всеобщая и нераздельная слитность и взаимопроникнутость внеположных частей», уничтожая пространственные границы между символами, рождёнными музыкой 94 .

Песня, танец и марш - искусство бисенсорное, существующее в пространстве и времени, но это иное пространство - не распыление бытия по Лосеву, а творение нового бытия из концентрации пространства - свобода от реального пространства и времени. Главной особенностью каждого из этих видов бытия является эстетичность, базирующаяся на символической природе выражения. Именно символическая слитность и взаимопроникновение всех взаимоисключающих начал (логического и алогического, жизни и смерти, войны и мира, души и тела, динамического

${ }_{92}^{2}$ Шелер М. Положение человека в Космосе. // Проблема человека в западной философии. М.: Прогресс, 1988. С. 76.

${ }_{93}$ Шеллинг Г.Ф.. Указ соч. С. 194.

94 Лосев А.Ф. Указ. соч. С. 53. 
и статического и др.) составляют тайну музыкальной образности в их стремлении открыть и выразить смысл бытия и вечную недосказанность этого смысла.

Отношение движения к музыке сопоставимо с отношением движения ко времени: движение - это качественно овеществлённое время, время воплощённое, наполненное содержанием и выраженное в своём ином. По Лосеву, «чистое музыкальное бытие есть всеобщая и нераздельная слитность и взаимопроникнутость последовательных частей, моментов - музыкальное время собирает разбитые и разбросанные куски бытия воедино, преодолевает тоску пространственного распятия бытия, воссоединяет пространственные и вообще взаимно отдалённые существенности с единством и цельностью времени их бытия» 95 .

Кроме гилетического, марш в той же мере воплощает в себе и логический момент сущности, то есть «воплощает невидимую мысль», по словам Аристотеля. Отношение движения к музыке сопоставимо с отношением движения ко времени: движение - это качественно овеществлённое время, время воплощённое, наполненное содержанием и выражением в своём ином.

Определение музыки как движения, лишённого образности и наглядности, находим у Гегеля: «Музыка аккомпанирует маршу солдат; сначала поддерживает человека правильностью, потом поглощает его в этом монотонном занятии, наполняя его душу гармонией. Она удаляет посторонние мысли и приятно занимает душу» 96. Гегель представляет нам три основных признака классического идеала: совершенное тело как выражение свободы; беспечная весёлость, но не самодовольство; отсутствие интимных чувств. К этому состоянию приводит нас жанр марша в полной степени в соединении движения с игрой на музыкальных инструментах и пением. Раскрывая более подробно признаки классического идеала, Гегель выделяет «гимн как победную хвалебную песнь, оду, как воспевание богов и героев, и народную песню»97, но маршу, к сожалению, Гегель отводит роль «за кулисами», отстраняя его от основных признаков классического идеала.

В современной эстетике музыки встречается мысль о том, что движение выступает

\footnotetext{
95 Там же. С. 63.

${ }^{96}$ Гегель Г. Указ. соч. С. 26-27.

97 Там же.
}

посредником между музыкальной и объективной реальностью. Советский искусствовед Т. Курышева, к примеру, пишет: «Образ движения, воспринятый в звучании, имеет достаточно опосредованные связи с реальностью. Промежуточной формой оказывается мир движения, уже поднятого до уровня художественного обобщения, и только между ним и музыкой рождается контакт, влекущий к взаимодействию систем и транспонированного языка. Эту высшую линию должно было выполнить специфическое искусство движения» ${ }^{8}$.

Согласившись с определением движения как гипостазированного времени, можно и марш охарактеризовать как гипостазированную музыку, имея в виду его бытийственную (фактическую) полноту. Эта предельная выраженность, воплощённость марша максимально приближает его к жизненному бытию человека, вплоть до полного стирания границ между этими двумя формами бытийствования. Если музыка в древности - символ всяческого освобождения от земных уз ради растворения в безумной стихии первожизни, то реализовывалось это освобождение и растворение через движение. «Если музыка - символ свободы, то танец как сочетание музыки и движений, предоставляют возможность ощутить эту свободу, завоевать и прожить её»99.

Чисто логически понятие музыки как искусства временного проще марша, который как жизнь существует во времени, пространстве, движении, становлении. Эта сложная синтетическая природа - главная причина того, что философы обходят марш своим вниманием: многие указывают на то, что марш искусство составное, синтетическое, а значит, его природа есть сумма определений других, составляющих это искусство. Но целое никогда не есть сумма частей, это нечто большее. Если признать музыку первоосновой мира, это повлечёт за собой вывод о том, что основой является не-бытие. Логичнее выглядит единство бытия и небытия, так как из этого единства вытекают все другие формы. Синтез как снятие противоположностей является не только последним, но и первым моментом развития, единство бытия и не-бытия в свёрнутом виде должно было предшествовать их дифференциации. Это признаётся в философских теориях, трактующих Универсум как ор-

\footnotetext{
${ }^{98}$ Курышева Т. Театральность и музыка. М.: Сов. композитор. 1984. С. 121.

${ }^{99}$ См.: Луговая Е.К. Указ. соч. С. 23.
} 
ганизм: «Первоначальное состояние организма, или его зародыш, по своим образующим элементам есть уже целый организм. Развитие должно состоять собственно в выделении и обособлении образующих форм и элементов организма ввиду их нового, уже вполне органического соединения ${ }^{100}$.

Марш, обладая двойственной философией, объединяет разные начала, он - в том числе и образ движения, а потому именно к нему относятся слова Гегеля: «Как время есть простая формальная душа природы, так движение есть понятие подлинной души мира» ${ }^{101}$.

Движение - сущность жизни, марш - выражение становления и жизни, и осуществляющегося не-бытия. Пространство и время только понятия, абстрагированные от единого процесса жизни, они познаются первоначально только в движущемся теле, «лишь в движении пространство и время действительны» ${ }^{102}$.

Марш - явление художественного творчества, а значит он - выразительная чувственная, символическая художественная форма. По Лосеву, «выражение, или форма, сущности есть становящаяся в нём сущность, неизменно струящаяся своими смысловыми энергиями. Она - потенция и залог всяческого функционирования сущности во мне. Она -твёрдо очерченный лик сущности, в котором отождествлён логический смысл с его алогической явленностью и данностью. Выражение есть символ» ${ }^{103}$. Будучи принципиальным равновесием логической и алогической стихий, художественная форма есть символ, то есть такое выражение, где в выраженном не более и не менее смысла, чем в выражающем, смысл полностью отождествляется со своим иным. Соотношение между художественной формой и смыслом отличается от соотношения означающего и значения. «Смысл художественного произведения не есть нечто отличное от самого произведения, художественная форма - не средство, не орудие, не повод для выражения смысла, она сама есть собственный смысл» ${ }^{104}$.

Мифу, часто упоминаемому Ницше и так воспетому романтиком Шеллингом, присуща отрешённость от обыденного смысла вещей. По Мамардашвили, введшему понятие

\footnotetext{
${ }^{100}$ Соловъёв В.С. Указ. соч. Т. 2. С. 143.

${ }^{101}$ Гегель Г. Энциклопедия философских наук. М.: 1975. T. 2. С. 63.

${ }^{102}$ Гегель Г.В.Ф. Там же. С. 63.

103 Лосев А.Ф. Диалектика художественной формы. М.: Мысль. 1995. С. 13.

104 Там же.
}

трансцендентности - отрешённости, искусство должно быть «местом для присутствия отсутствующей реальности» ${ }^{105}$ высших ценностей и смыслов. Но в отличие от поэтической отрешённости, миф никогда не перестаёт быть живой, вещественной и телесной реальностью. По Лосеву, миф - это «в словах данная чудесная личностная история» ${ }^{106}$. По Шеллингу, миф - «символ, чувственное и неразложимое выражение идеи, художественное мышление вообще» ${ }^{107}$. Но если первой формой человеческого языка является язык всеобщего телесного жеста, то первоначально мифологическое мироощущение выражалось не в повествовательных формах, а в действиях - обрядах и танцах. Задолго до развития истории и цивилизации человек был увлечён магией ритмического движения, которое он наблюдал в природе и в небе. Символические движения воспринимались как вечная связь между сейчас и потом, рождением и смертью, телесным и духовным. Эта связь осуществляется между человеком и природой, между людьми при отсутствии понимания между ними на уровне языка.

Мир движения также абсолютен, самоценен и самоопределён, как и мифологическая реальность. Движение является зримой иллюстрацией вечности. Миф как вечность не есть покой, но непрерывное движение. Сущность мифа Лосев формулирует как «миф есть магическое имя» ${ }^{108}$, потому что именно здесь происходит диалектический синтез личности и её выраженности. Миф не мыслим вне ритуала, это ритуал в его словесном выражении, а ритуал, в свою очередь, может быть понят как миф в действии.

Лосев получает четыре основных вида художественной формы: словесная, живописная, музыкальная и тектоническая формы, последняя есть самостоятельно существующая сущность, сама включающая три вида, каждому из которых также соответствует определённый момент сущности. В этой системе Лосева марш относится к тектонической форме и соответствует третьему моменту сущности.

Первоформа эстетического должна быть ближе всего к основе мира, которую вслед за Шопенгауэром, Шелером и Лосевым видим в волевом, безумном, безудержном стрем-

\footnotetext{
105 Мамардашвили М. Дъявол играет нами, когда мы не мыслим точно. Театр. 1989. № 3. С. 95.

${ }^{106}$ Лосев А.Ф. Диалектика мифа. М. Академический проект. 2008. С. 24

${ }_{107}$ Шеллинг Ф. Указ. соч. С. 110.

108 Лосев А.Ф. Указ. соч. С. 24.
} 
лении, в творческом порыве, «глухой и слепой» мощи бытия, в которой нет ничего и всё возможно. В музыке и движениях - танце и марше - требование наглядности и объективной направленности духа перестаёт быть актуальным. В отличие от изобразительного искусства и поэзии; создаётся впечатление, что пропадает сам объект познания, он переносится на субъекта, на личность творца и участника, внешние причины здесь не важны, всё внимание направлено на внутреннюю эмоциональную жизнь воли. Эти искусства сосредотачиваются на раскрытии мира в себе самом. При этом не надо искать причин и внешних смыслов события или явления, ибо, по Шопенгауэру, «звуки уже как действия производят эстетическое впечатление и нам не нужно, как при созерцании, восходить для этого к их причине» ${ }^{109}$.

В поисках высшего синтеза многие философы Европы обращались к Древней Греции и её аттической трагедии, которая для искусствоведов остаётся единственным в истории человечества счастливым случаем органического соединения двух противоположных начал - аполлоновского и дионисийского, образного и безобразного искусства: «С их двумя божествами искусств, Аполлоном и Дионисием, связано наше знание о той огромной противоположности в происхождении и целях, которую мы встречаем в греческом мире между искусством пластических образов - аполлоническом - и непластическим искусством музыки - искусством Диониса; эти два столь различных стремления действуют рядом одно с другим, чаще всего в открытом раздоре между собой и взаимно побуждая друг друга ко всё новым и более мощным порождениям, дабы в них увековечить борьбу названных противоположностей» ${ }^{110}$. Аполлоновским началом греческой трагедии является художественный мир олимпийских богов, в котором греки видели своё высшее отражение. Эта составляющая является обнаружением личности, культом индивида. Всё, что находится в аполлоновской части греческой трагедии, отличается простотой, прозрачностью и красотой, основанной, между прочим, на геоцентрической модели мира. Дионисийским началом они считали всю музыку, участвующую в постановке трагедии. Но и в этой трагедии марш укоренился самым простым и естественным способом, объединив в себе

\footnotetext{
${ }^{109}$ Шопенгауэр А. Указ. соч. С. 316.

${ }_{110}$ Ницие $\Phi$. Рождение трагедии из духа музыки. СПб.: Азбука-классики. 2007. С. 43.
}

аполлоновское и дионисийское - он явился аккомпанементом при выходе на сцену отдельных героев или целых хоров при смене сцен.

Жизнь человека, как и культуры, протекает на границе двух миров - природы и социокультурных ценностей. Хорошо охарактеризовал положение человека между природным и сверхчувственным мирами Ницше: «Человек - это канат, протянутый между животным и сверхчеловеком, - канат, протянутый над пропастью... Человек велик именно тем, что он есть мост, а не цель; за что можно любить человека - так за то, что он есть переход и погибель» ${ }^{111}$. Жизнь человека никогда не сводилась к удовлетворению материальных потребностей, в нём всегда было великое стремление выйти из суетности и сиюминутности своего существования в область вечных и непреходящих ценностей. Дифференциация человеческой деятельности на трудовую и мистериальную сделало возможным говорить о существовании двух культур: материальной (деловой) и праздничной. Любое действие в деловой культуре носит ограниченный, конечный характер и подчинено определённой цели - практическому результату. Это в большей мере относится к делу войны для достижения мира или мирная деятельность по недопущению войны. Деятельность же в праздничной культуре сохраняет в себе первоначальную синкретическую многозначность, она направлена на осуществление связи двух миров, как при связи мира живых и мира мёртвых, и определяется как самоцельная и символическая.

Поэтому праздник был истоком и началом как для игры, так и для искусства. Связь искусства и игры можно объяснить их внутренним родством - «искусство есть наиболее оригинальная форма игры, она есть высочайшая возможность посредством «видимости» явить сущность» ${ }^{112}$. Отличие от понятийных структур не означает, что искусство и игра чужды пониманию и смыслу, а наоборот, отказ от логики здравого смысла позволяет им обратиться к высшим смыслам, к познанию сущ-

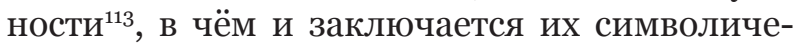
ская природа. В игре и искусстве человек действительно способен познавать окружающий

\footnotetext{
${ }^{111}$ Ницие Ф. Так говорил Заратустра. М. 1990. С. 11. ${ }_{112}$ Финк Э. Основные феномены человеческого бытия. Проблемы человека в западной философии. М.: Мысль. 1988. С. 401.

${ }^{113}$ См.: Гадамер Г.Г. Истина и метод. М.: Прогресс. 1988. C. 162.
} 
его мир, но не через его пассивное отражение, а в свободном творческом исполнении жизни, когда сценой становится вся вселенная, а персонажами действия могут стать сверхреальные сущности. Состояние «катарсиса души» мы, как и в марше, встречаем и в игре, где наслаждаемся своим свободным, деятельным бытием, испытывая удовлетворение от особенного смешения реальности и нереальности. В игре человек пробивается к подлинному бытию, к общению с первоистоком, откуда и произошло прочное, устойчивое и неизменное бытие. Для движущегося в ритме человека характерна не только двойственность сознания, но и двойственность собственного тела, которое становится для него и многих игрушкой. Именно в движении обнаруживается смысловое измерение человеческого тела.

\section{2. Дуальность и эстетика марииа}

Материал марша понимается двояко: как выразительная форма, это виртуальное пространство, время, движение, с этим материалом имеет дело художник, он конструирует пространство в живописи, время в музыке, движения в танце; как физическая форма, в которой воплощается виртуальный материал. Этот физический материал равнодушен к выражаемому в нём смыслу, то есть, из куска мрамора можно высечь и Венеру и Зевса, или выстелить дорогу, но без самого материала мы не увидим шедевра. Это выражение полностью оправдано в любом другом виде искусства, кроме танца и марша, материалом которого служит живое тело, а оно уже содержит смысл в себе самом. Продолжая мысль Хайдеггера о том, что «материал (вещество) не исчезает в произведении искусства, а наоборот, выступает в истинном своём свете» ${ }^{114}$, мы утверждаем, что тело и дух становится подлинно свободным при погружении в музыку. Поскольку наше тело - центр и условие субъективности, то движение под музыку постоянно превосходит свою материальную структуру, оно всегда полно смысла и выходит за рамки материала.

В некотором смысле все искусства связаны с телом, они осуществляются через движение, через жизнь. Именно тело как материал жизни и его подвижная сущность лежит в основе всех творческих процессов.

Конечно, и к телу можно подходить как к объекту, неживому материалу, инструменту.

\footnotetext{
${ }^{114}$ Хайдеггер $M$. Исток художественного творения.
} М.: Академический проект, 2008. С. 10.
Это становится возможным, когда тело является объектом внимания как предмет рядом с другими предметами, как оркестр для композитора, краски для художника. Человек никогда не может стать полностью объектом, тело проживается человеком, но не познаётся им. В экстатическом состоянии марша мы не замечаем своего тела, не рефлектируем по поводу себя и своих действий, мы спонтанно проживаем данный момент в марше, преследуя общую, свыше поставленную цель.

Подлинное художественное воплощение идеи жизни и свободы происходит в единении души и тела. Долгое время в западной философии преобладало убеждение в том, что сущность человека составляет его мышление. Тело при этом мыслилось как временная оболочка души, лишь затрудняющая и затемняющая чистые акты сознания, а в лучшем случае служащая для него покорным инструментом. По Шопенгауэру, «воля - это априорное познание тела, а тело - апостериорное познание воли» ${ }^{115}$, если учесть, что музыка для него является отпечатком самой воли, а тело ассоциируется с движением. То чувство, которое вызывает марш, укрепляет волю и заставляет двигаться тело, но если волю не обуздать, это приведёт к неприятным последствиям. Лишь воля является основой интеллекта и ведёт к познаниям.

В самой музыке заложено стремление стать зримой: музыка - условие жизни, которое есть всегда становление и изменение конкретных форм бытия, поэтому заразительность музыки можно понимать как влечение к движению.

На рубеже XIX-XX веков, как показал исторический опыт, многие философы стали отказываться от основоположений классической философской традиции, и от понятия «трансцендентального субъекта мысли», лишённого пространственности и временных характеристик. Теперь тело понимается как самоуправляемая система, как осмысленное и действующее, так как именно в действии душа и тело совпадают, распадаются же они только после смерти.

Экзистенциализм - течение середины XX столетия - выдвигает на первый план абсолютную уникальность человеческого бытия, не допускающую выражения на языке понятий, который способен помочь в постижении универсальных сущностей, но оказывается бесполезным в объяснении не-

${ }^{115}$ Шопенгауэр А. Указ. соч.. С. 5. 
повторимости каждой человеческой души. Осознание уникальности человеческого бытия привело к эволюции феноменологической философии в экзистенциальную феноменологию, с новой постановкой проблемы человека и оттеснением на второй план проблемы сознания.

В логике всё есть, в экзистенции, как в танце и марше, - всё становится. «Бытие в мире»у Хайдеггера длится во времени, движении, становлении. Манера движения человека выражает определённое отношение ко времени, пространству и силе, что равнозначно демонстрации своего особого отношения к миру. Живое тело привлекает философов своей способностью мыслить на довербальном уровне. Наше бытие в мире не детерминировано изначально, оно открыто или может быть открыто. Именно свобода движения лежит в основе всех более абстрактных представлений о свободе.

Как искусство марш рассматривается с трёх позиций: отношения, складывающиеся между художником и продуктом его творчества, проблемы эстетического восприятия и понимания искусства, анализ марша как такового. Как нечто большее, самостоятельное имманентное явление, марш может рассматриваться ещё с других позиций - как средство достижения цели, средство утверждения себя в мире, - это прикладное значение.

В настоящее время в эстетике философский спор концентрируется вокруг природы произведения искусства и его относительной самостоятельности. Выразительная форма не равна физической форме произведения искусства, а пребывает в иллюзорном виртуальном мире, она не просто воспринимается как нечто данное, но является результатом работы творческого воображения. За чувственными впечатлениями мы переживаем целый мир иных, в которых только и проявляется вся полнота и глубина произведения. Художественная форма отлична от материала искусства, она создаётся одним видением и не имеет практических исключений.

В искусстве движений (особенно в танце) огромную роль играет элемент динамической силы, являющийся их жизненным пульсом, их живым дыханием. Как и законченное произведение любого другого вида искусства, марш содержит в себе мир, в который можно «войти». Этот мир является частью реального мира и плотно соприкасается со множеством вещей внутри него.
Для обыденной жизни тело - средство удовлетворения чувственных потребностей, человек экономит время и энергию для получения определённого результата. Марш может быть ограничен внешними обстоятельствами, но все эти ограничения не присущи ему внутренне. Движение, пространство и время - это те элементы, которые дают маршу жизнь, абстракции, пока они не воплотятся в теле, в котором они воспринимаются как живые. Обычно мы не замечаем пространство и время, но марш, как и другие виды искусства, делает их наглядными и осязаемыми. Все искусства объединены присутствием в них времени и пространства. Так, музыка представляет собой однонаправленную последовательность звуков и в этом смысле является чисто временным искусством, но благодаря памяти эта последовательность звуков воспринимается нами в сложном композиционном построении: как соотношение, развитие, варьирование, контрастирование музыкальных тем. Поэтому отрицание существования музыкального пространства, которое не тождественно реальному пространству, равнозначно отрицанию возможности существования музыки вообще. Также необходимо признать существования времени в пространственных искусствах, оно присутствует в них двояко: как время восприятия произведения, ибо ни одно произведение живописи, скульптуры или архитектуры не поддаётся мгновенному раскрытию, а требует длительного ознакомления; произведения изобразительного искусства не являются мгновенным слепком, а концентрируют в себе и прошлое, и настоящее, и будущее, в нём спрессован целый ряд временных пластов, таким образом, пространство и время тесно связаны.

Внутренний мир марша существует не в физическом измерении пространства и времени. Он занимает в реальном пространстве особое художественное пространство, а в реальном времени - особое художественное время. Эти двойные пространства и время не обязательно перекрывается одно другим.

Марш обладает собственным имманентным настоящим. Он управляет временем, так как через движение придаёт времени повторяемую структуру. В этом смысле марш - весомая и зримая сущность, с чёткими очертаниями и ритмами. Марш мы видим и чувствуем внутри себя через внутреннее время нашего тела. Произведение искусства есть нечто бесконечное, оно «заключает в себе весь мир 
и представляет собой микрокосм, неисчерпаемый в целом и понятный только в некоторых отдельных внешних подробностях» ${ }^{116}$.

Не мудрено поэтому видеть толпы марширующих людей, охваченных всеобщим порывом и не чувствующих времени. Такие явления происходили в истории в высших своих крайних проявлениях. Например, при нацизме, когда музыка служила поощрению самых низменных чувств, самых безобразных черт характера. Время и пространство не существует - есть только цель и марш. И когда сочиняют марш, создавая его определённую пространственно-временную структуру, то время и пространство становятся для его создателей объективными данными.

Ингарден, выявляя отличия между произведениями музыкального искусства и множеством его конкретных исполнений, указывает на то, что в противоположность отдельным исполнениям само музыкальное произведение не имеет определённой пространственной локализации и не является процессом. Bсе части произведения существуют одновременно, а не последовательно, как в исполнении: «Музыкальное произведение представляется нам предметом в особом смысле надвременным, который характеризуется вместе с тем внутренней, имманентной ему временной структурой» ${ }^{117}$. Каждое произведение, будь то марш, песня или танец, содержит в себе какое-то количество частей - фаз, в момент его возникновения все части существуют вместе, и только в исполнении они приобретают многофазовый характер. Однако и само по себе произведение предусмотрено как процесс. Ингарден приходит к выводу, что «само произведение является как бы интенциональным эквивалентом высшего порядка, свойственным всему множеству интенциональных актов, осуществляемых реальными людьми» ${ }^{118}$. В музыкальном произведении мы имеем дело не с реальным предметом, а с чистым интенциональным предметом высшего порядка. Однако, существование чисто интенциональных предметов предполагает существование некоторых реальных объектов, делающих первые доступными для многих субъектов: это автор произведения и средство его закрепления. Развивая эту мысль, выделяем в марше и немузыкальные моменты: квазивременная структура,

\footnotetext{
${ }^{116}$ Шпенглер О. Закат Европы. М.: Мысль, 1998. Т. 1. C. 150.

117 Ингарден Р. Исследования по эстетике. М. 1962. C. 469 .

${ }_{118}$ Там же. С. 528.
}

абстрактная форма, эмоциональные качества, изобразительные мотивы и др.

Итак, марш сочетает в себе, по меньшей мере, две реальности. Как искусство, пространственно-временное бытие марша тождественно времени и пространству, в котором мы живём, а исходя из целей, существуют образы воображаемые. Марш больше, чем просто движение или музыка. Физическое движение само по себе есть просто грубый материал, пока оно не будет оформлено с целью выражения и презентации. Марш включает в себя порою и слова, поэтому имеет возможность выражать, говорить, открывать уникальную правду бытия. Движения в нём самоценны, как ценны любые движения, но марш в целом отсылает нас к ряду явлений, выступающих за рамки простого движения. Марш всегда есть образ, символ, возникающий из соединения движений, музыки, а иногда слов. Каждая составляющая вносит различия в целое, хоть она и не имеет определённого значения, но вносит свой вклад в выразительные возможности и значения этого целого. Марш не просто выразителен, он метафоричен: он использует человеческие движения, как поэзия слова. Движения не являются знаками, которые указывают на значение, они разумны и понятны сами по себе, как способность любого двигаться.

Как и другие виды искусства, марш соединяет в себе два вида эстетической чувственности: прекрасное и возвышенное, но выраженные особенным способом. Выразительная форма понимается как объективация субъективного опыта и субъективация природы эстетическое всегда связано с субъективным. То, с чем с трудом справляется разговорный язык, успешно осуществляется в произведениях музыкального искусства. Каждое произведение искусства и есть такой образ, причина же того, что оно может указывать на элементы внутренней жизни - в изоморфности структур жизни и искусства, причём не материала искусства, а создаваемого художником образа. Этот образ выражает саму природу чувства, а не чувства исполнителя, и потому он объективен.

Марш и танец рождает своё собственное значение. «Искусство их реалистично, они не подобны мечте или сну, они не могут быть воображаемыми, они реальны и переводят непостижимое и трансцендентное, они способны отражать предметный мир, самую жизнь» ${ }^{119}$. Если марш нельзя назвать самой жизнью, он

119 Луговая Е.К. Указ. соч. С. 34. 
связан с жизнью через свою основу - живое тело - и через движения, взятые из нашего цельного существования в мире, через шаг, манеру ходьбы, позу.

\section{ЗАКЛЮЧЕНИЕ}

Марш обладает полнотой смыслового бытия: материи (логоса), сущности (эйдоса) и текучести - цельной сущности в его самотождественности и различенности, покое и становлении, а потому с большим основанием, чем музыка, может быть соотнесён с первоначалом бытия. Марш как художественный феномен, будучи равновесием логической и алогической стихий, есть символ, где «художественная форма не есть повод или средство для выражения чуждого смысла, а сама есть явленный смысл» ${ }^{120}$.

Марш выступает как объединяющий принцип, как живая энергия, выявленная желанием в достижении той или иной цели, он органически объединяет в себе два противоположных начала художественной деятельности, аполлоновское и дионисийское, образное и без-образное искусства. В марше выявляется полнота экзистенции, который уникален своим материалом, содержащим смысл уже в себе самом, являющимся центром и условием субъективности. Он обладает собственным имманентным настоящим.

Развивая свою собственную логику, свою собственную рациональную целостность, марш, содержание, значение и смысл которого всегда касается высших сущностей, таких как цель или жизнь, вносит метафизическое в физическое, трансцендентное в опыт жизни.

Будучи формой участия в жизни и культуре и одним из способов их создания, марш служит самым благим целям, как уже неоднократно говорилось выше - проникновению в души и сердца людей с целью их консолидации и самосохранения; в марше выражена воля. Марш как один из самых древних видов искусства, дающий правду бытия, в любой своей форме содержит элемент сакральности. В марше может быть ярче, чем в иных видах художественного творчества, нарастает согласие между личным и общим, войной и миром, жизнью и смертью. Человек не расстаётся со своей неповторимой индивидуальностью, но через движение и единение присоединяется к общей интерсубъективной духовной субстанции. Марш может иметь эстетическую ценность, даже когда он исполняется без какой-либо общей цели - это всегда и есть искусство.

Будучи неотъемлемым элементом бытия, марш никогда не исчезнет, являясь одним из основных, первичных жанров музыки, марш никогда не изменится. Со временем он будет лишь развиваться, обретая новые формы и черты посредством изобретения новых инструментов и способов интерпретации. Как элемент дуального мира, марш будет сохранять свои позиции и роль нематериального моста между миром и войной, жизнью и смертью, бытием и небытием, искусством и ремеслом. В будущем маршу будет обращено более пристальное внимание как со стороны учёных, так и со стороны практиков, когда потребуется найти новую национальную идею, консолидировать общество, он будет использован как великолепный инструмент для физического и патриотического воспитания. Как никогда не иссякнет жизнь, так никогда не иссякнет и потребность в этом виде искусства - марше.

\section{Список литературы:}

1. Августин А. Исповедь. М.: Ренессанс. 1991.

2. Артхашастра Каутильи. / Самозванцев А.М. М.: Восточная литература РАН. 2009.

3. Афиней. Пир мудрецов. В 15 кн. Т. 1. Кн. 2. М.: Наука. 2003. С. 38.

4. Бердяев Н.А. Футуризм на войне. М.: Канон+. 2004, С. 40.

5. Библия: Исход, Числа.

6. Вейдер Б. Блистательный Бонапарт. М.: Международные отношения, 1992.

7. Гадамер Г.Г. Истина и метод. М.: Прогресс. 1988.

8. $\quad$ Гегель Г.В. Курс эстетики, или Наука изящного. Кн. II, Музыка, эпическая поэзия. М. 1869.

9. Гегель Г.В. Лекции по эстетике. Кн. III. М.: Институт философии АН СССР. 1958.

10. Гегель Г.В. Энциклопедия философских наук. М.: 1975. Т. 2.

11. Гегель Г.В. Философия религии. М.: Мысль. 1977. Т. 2.

120 Там же. С. 36. 
12. Гулыга А.В. Немецкая классическая философия. М.: 1986.

13. Дева Б. Чайтанья. Индийская музыка. М.: Музыка, 1980.

14. Достоевский Ф.М. Дневник писателя. Сентябрь-ноябрь 1877 года. Л.: Наука, 1984.

15. Залесский П.И. Грехи старой России и её армии. Цит. по: Григорьев А.Б. Философия войны: Российский военный сборник. М.: Изд. центр «Анкил-воин», 1995.

16. Ингарден Р. Исследования по эстетике. М. 1962.

17. Иосиф Флавий. Иудейские древности. СПб. 1900. В 2 т. Т. 2. Гл. ХI.

18. К Кант И. Критика способности суждения. Сочинения в 6 томах. Т. 5. М.: Мысль, 1966.

19. К Кант И. Трактат «К вечному миру». Сочинения в 6 томах. Т. 6. М.: Мысль. 1966.

20. Кастнер Г. Общее руководство по военной музыке. Париж. 1847.

21. Клаузевиц К. О войне. М.: Эксмо, СПб.: Мидгард. 2007.

22. Курышева Т. Театральность и музыка. М.: Сов. композитор. 1984.

23. Лосев А.Ф. Античная музыкальная эстетика. М.: Госмузиздат. 1960.

24. Лосев А.Ф. Диалектика художественной формы. М.: Мысль. 1995.

25. Лосев А.Ф. Диалектика мифа. М. Академический проект. 2008.

26. Лосев А.Ф. Музыка как предмет логики. М.: Издание автора. 1927.

27. Луговая Е.К. Философия танца. СПб. 2008.

28. Макиавелли Н. О военном искусстве. СПб.: АМФОРА. 1999.

29. Мамардашвили М. Дъявол играет нами, когда мы не мыслим точно. Театр. 1989. № 3.

30. Ницше Ф. Воля к власти. М. Наука.1994.

31. Ницше Ф. Весёлая наука. СПб.: Азбука. 1997.

32. Ницше Ф. Так говорил Заратустра. М.: Азбука. 1990.

33. Ницше Ф.В. Песни Заратустры. СПб.: Азбука. 1997.

34. Ницше Ф. Рождение трагедии из духа музыки. СПб.: Азбука-классики. 2007.

35. Пенской В.В., Пенская Т.М. Очерки истории военного дела Византии. Белгород.: ООО ИПЦ «ПОЛИТЕРРА». 2011.

36. Платон. Лахес: диалог философа Платона о мужестве. М.: Унив. тип.. 1890.

37. Платон. Диалоги. Алкивиад. М.: Мысль. 1986.

38. Плутарх. О музыке. Петроград: Государственное издательство. 1922.

39. Плутарх. Сравнительные жизнеописания. М.: Альфа-книга: 2008. Ликург и Нума Помпилий, гл. 22. Агезилай и Помпей, гл.19.

40. Послания св. Афанасия Великого, архиепископа Александрийского, к Аммуну монаху // Книга Правил святых апостол, святых Соборов Вселенских и поместных и святых отец. M. 2004.

41. Руссо Ж.Ж. Суждение о вечном мире // Трактаты о вечном мире. М.: Соцэкгиз. 1963.

42. Сисаури В.И. Церемониальная музыка Китая и Японии. СПб. Изд. СПбГУ, 2008.

43. Соловьёв В.С. Философские начала цельного знания. Сочинения в 2-х т. М.: Мысль. 1988, T. 1.

44. Страбон. География, кн. I, гл. 25.

45. Сунь-цзы. Искусство стратегии. М.: Эксмо, СПб.: Мидгард, 2006.

46. Ткаченко Г.А. Космос, музыка и ритуал: Миф и эстетика в «Люйши чуньцю». М.: Наука. 1990.

47. Толковый словарь русского языка / Шведова Н.Ю. М. РАН ИРЯ им. В.В. Виноградова. 2007.

48. Феодорит Киррский. Толкование на послание к евреям. СПб., 1843.

49. Финк Э. Основные феномены человеческого бытия. Проблемы человека в западной философии. М.: Мысль. 1988.

50. Хайдеггер М. Исток художественного творения. М.: Академический проект, 2008.

51. Ц Цертелев Д. Эстетика Шопенгауэра. СПб. 1890.

52. Чечотт В.А. История музыки. Киев. 1890.

53. Шелер М. Положение человека в Космосе. // Проблема человека в западной философии. М.: Прогресс, 1988.

54. Шеллинг Ф.В.Й. Философия искусства. М.: Мысль. 1966.

55. Шопенгауэр А. Мир как воля и представление. Перевод А. Фета. С-Петербург. 1881.

56. Ш Шенглер О. Закат Европы. М.; Мысль, 1998. Т. 1.

57. Энциклопедия «Музыкальные инструменты». М. «Дека-ВС». 2008. 
58. Попов Е.А. Понятие государства как ценностно-смысловой системы в философии права и философии государственности // NB: Вопросы права и политики. - 2013. - 2. - С. 193 - 217. URL: http://www.e-notabene.ru/lr/article_454.html

59. Ю.В. Наумов Религиозно-философские идеи наследия Ф. Ницше и В. Соловьева (Компаративистский анализ). // Философия и культура. - 2011. - 6. - С. $114-120$.

\section{References (transliteration):}

1. $\quad$ Avgustin A. Ispoved'. M.: Renessans. 1991.

2. $\quad$ Artkhashastra Kautil'i. / Samozvantsev A.M. M.: Vostochnaya literatura RAN. 2009.

3. $\quad$ Afinei. Pir mudretsov. V 15 kn. T. 1. Kn. 2. M.: Nauka. 2003. S. 38.

4. Berdyaev N.A. Futurizm na voine. M.: Kanon+. 2004, S. 40.

5. Bibliya: Iskhod, Chisla.

6. $\quad$ Veider B. Blistatel'nyi Bonapart. M.: Mezhdunarodnye otnosheniya, 1992.

7. Gadamer G.G. Istina i metod. M.: Progress. 1988.

8. Gegel' G.V. Kurs estetiki, ili Nauka izyashchnogo. Kn. II, Muzyka, epicheskaya poeziya. M. 1869.

9. Gegel' G.V. Lektsii po estetike. Kn. III. M.: Institut filosofii AN SSSR. 1958.

10. Gegel' G.V. Entsiklopediya filosofskikh nauk. M.: 1975. T. 2.

11. Gegel' G.V. Filosofiya religii. M.: Mysl'. 1977. T. 2.

12. Gulyga A.V. Nemetskaya klassicheskaya filosofiya. M.: 1986.

13. Deva B. Chaitan'ya. Indiiskaya muzyka. M.: Muzyka, 1980.

14. Dostoevskii F.M. Dnevnik pisatelya. Sentyabr'-noyabr' 1877 goda. L.: Nauka, 1984.

15. Zalesskii P.I. Grekhi staroi Rossii i ee armii. Tsit. po: Grigor'ev A.B. Filosofiya voiny: Rossiiskii voennyi sbornik. M.: Izd. tsentr «Ankil-voin», 1995.

16. Ingarden R. Issledovaniya po estetike. M. 1962.

17. Iosif Flavii. Iudeiskie drevnosti. SPb. 1900. V 2 t. T. 2. Gl. XI.

18. Kant I. Kritika sposobnosti suzhdeniya. Sochineniya v 6 tomakh. T. 5. M.: Mysl', 1966.

19. Kant I. Traktat «K vechnomu miru». Sochineniya v 6 tomakh. T. 6. M.: Mysl'. 1966.

20. Kastner G. Obshchee rukovodstvo po voennoi muzyke. Parizh. 1847.

21. Klauzevits K. O voine. M.: Eksmo, SPb.: Midgard. 2007.

22. Kurysheva T. Teatral'nost' i muzyka. M.: Sov. kompozitor. 1984.

23. Losev A.F. Antichnaya muzykal'naya estetika. M.: Gosmuzizdat. 1960.

24. Losev A.F. Dialektika khudozhestvennoi formy. M.: Mysl'. 1995.

25. Losev A.F. Dialektika mifa. M. Akademicheskii proekt. 2008.

26. Losev A.F. Muzyka kak predmet logiki. M.: Izdanie avtora. 1927.

27. Lugovaya E.K. Filosofiya tantsa. SPb. 2008.

28. Makiavelli N. O voennom iskusstve. SPb.: AMFORA. 1999.

29. Mamardashvili M. D”yavol igraet nami, kogda my ne myslim tochno. Teatr. 1989. № 3.

30. Nitsshe F. Volya k vlasti. M. Nauka.1994.

31. Nitsshe F. Veselaya nauka. SPb.: Azbuka. 1997.

32. Nitsshe F. Tak govoril Zaratustra. M.: Azbuka. 1990.

33. Nitsshe F.V. Pesni Zaratustry. SPb.: Azbuka. 1997.

34. Nitsshe F. Rozhdenie tragedii iz dukha muzyki. SPb.: Azbuka-klassiki. 2007.

35. Penskoi V.V., Penskaya T.M. Ocherki istorii voennogo dela Vizantii. Belgorod.: OOO IPTs «POLITERRA». 2011.

36. Platon. Lakhes: dialog filosofa Platona o muzhestve. M.: Univ. tip.. 1890.

37. Platon. Dialogi. Alkiviad. M.: Mysl'. 1986.

38. Plutarkh. O muzyke. Petrograd: Gosudarstvennoe izdatel'stvo. 1922.

39. Plutarkh. Sravnitel'nye zhizneopisaniya. M.: Al'fa-kniga: 2008. Likurg i Numa Pompilii, gl. 22. Agezilai i Pompei, gl.19.

40. Poslaniya sv. Afanasiya Velikogo, arkhiepiskopa Aleksandriiskogo, k Ammunu monakhu // Kniga Pravil svyatykh apostol, svyatykh Soborov Vselenskikh i pomestnykh i svyatykh otets. M. 2004.

41. Russo Zh.Zh. Suzhdenie o vechnom mire // Traktaty o vechnom mire. M.: Sotsekgiz. 1963.

42. Sisauri V.I. Tseremonial'naya muzyka Kitaya i Yaponii. SPb. Izd. SPbGU, 2008. 
43. Solov'ev V.S. Filosofskie nachala tsel'nogo znaniya. Sochineniya v 2-kh t. M.: Mysl'. 1988, T. 1.

44. Strabon. Geografiya, kn. I, gl. 25.

45. Sun'-tszy. Iskusstvo strategii. M.: Eksmo, SPb.: Midgard, 2006.

46. Tkachenko G.A. Kosmos, muzyka i ritual: Mif i estetika v «Lyuishi chun'tsyu». M.: Nauka. 1990.

47. Tolkovyi slovar' russkogo yazyka / Shvedova N.Yu. M. RAN IRYa im. V.V. Vinogradova. 2007.

48. Feodorit Kirrskii. Tolkovanie na poslanie k evreyam. SPb., 1843.

49. Fink E. Osnovnye fenomeny chelovecheskogo bytiya. Problemy cheloveka v zapadnoi filosofii. M.: Mysl'. 1988.

50. Khaidegger M. Istok khudozhestvennogo tvoreniya. M.: Akademicheskii proekt, 2008.

51. Tsertelev D. Estetika Shopengauera. SPb. 1890.

52. Chechott V.A. Istoriya muzyki. Kiev. 1890.

53. Sheler M. Polozhenie cheloveka v Kosmose. // Problema cheloveka v zapadnoi filosofii. M.: Progress, 1988.

54. $\quad$ Shelling F.V.I. Filosofiya iskusstva. M.: Mysl'. 1966.

55. Shopengauer A. Mir kak volya i predstavlenie. Perevod A. Feta. S-Peterburg. 1881.

56. Shpengler O. Zakat Evropy. M.; Mysl', 1998. T. 1.

57. Entsiklopediya «Muzykal'nye instrumenty». M. «Deka-VS». 2008.

58. Popov E.A. Ponyatie gosudarstva kak tsennostno-smyslovoi sistemy v filosofii prava i filosofii gosudarstvennosti // NB: Voprosy prava i politiki. - 2013. - 2. - C. $193-217$.

URL: http://www.e-notabene.ru/lr/article_454.html

59. Yu.V. Naumov Religiozno-filosofskie idei naslediya F. Nitsshe i V. Solov'eva (Komparativistskii analiz). // Filosofiya i kul'tura. - 2011. - 6. - C. $114-120$. 